\title{
Willingness to pay for contraceptive vaginal rings in Kenya
}

Wilson Liambila

Population Council

Deepa Rajamani

Population Council

Francis Obare

Population Council

Saumya RamaRao

Population Council

Harriet Birungi

Population Council

See next page for additional authors

Follow this and additional works at: https://knowledgecommons.popcouncil.org/departments_sbsr-rh

Part of the Demography, Population, and Ecology Commons, Family, Life Course, and Society Commons, International Public Health Commons, and the Women's Health Commons How does access to this work benefit you? Let us know!

\section{Recommended Citation}

Liambila, Wilson, Deepa Rajamani, Francis Obare, Saumya RamaRao, Harriet Birungi, and Heather Clark. 2015. "Willingness to pay for contraceptive vaginal rings in Kenya." New York: Population Council. 


\section{Authors}

Wilson Liambila, Deepa Rajamani, Francis Obare, Saumya RamaRao, Harriet Birungi, and Heather Clark 


\title{
WILLINGNESS TO PAY FOR CONTRACEPTIVE VAGINAL RINGS IN KENYA
}

\author{
Wilson Liambila \\ Deepa Rajamani \\ Francis Obare \\ Saumya RamaRao \\ Harriet Birungi \\ Heather Clark
}




\section{ק户}

The Population Council confronts critical health and development issues-from stopping the spread of HIV to improving reproductive health and ensuring that young people lead full and productive lives. Through biomedical, social science, and public health research in 50 countries, we work with our partners to deliver solutions that lead to more effective policies, programs, and technologies that improve lives around the world. Established in 1952 and headquartered in New York, the Council is a nongovernmental, nonprofit organization governed by an international board of trustees.

Population Council

General Accident House

Ralph Bunche Road

Nairobi, Kenya

Tel: +254202713480

Fax: +254202713479

popcouncil.org

Suggested citation: Liambila, Wilson, Deepa Rajamani, Francis Obare, Saumya RamaRao, Harriet Birungi, and Heather Clark. 2015. "Willingness to Pay for Contraceptive Vaginal Rings in Kenya." New York: Population Council. 


\section{Table of Contents}

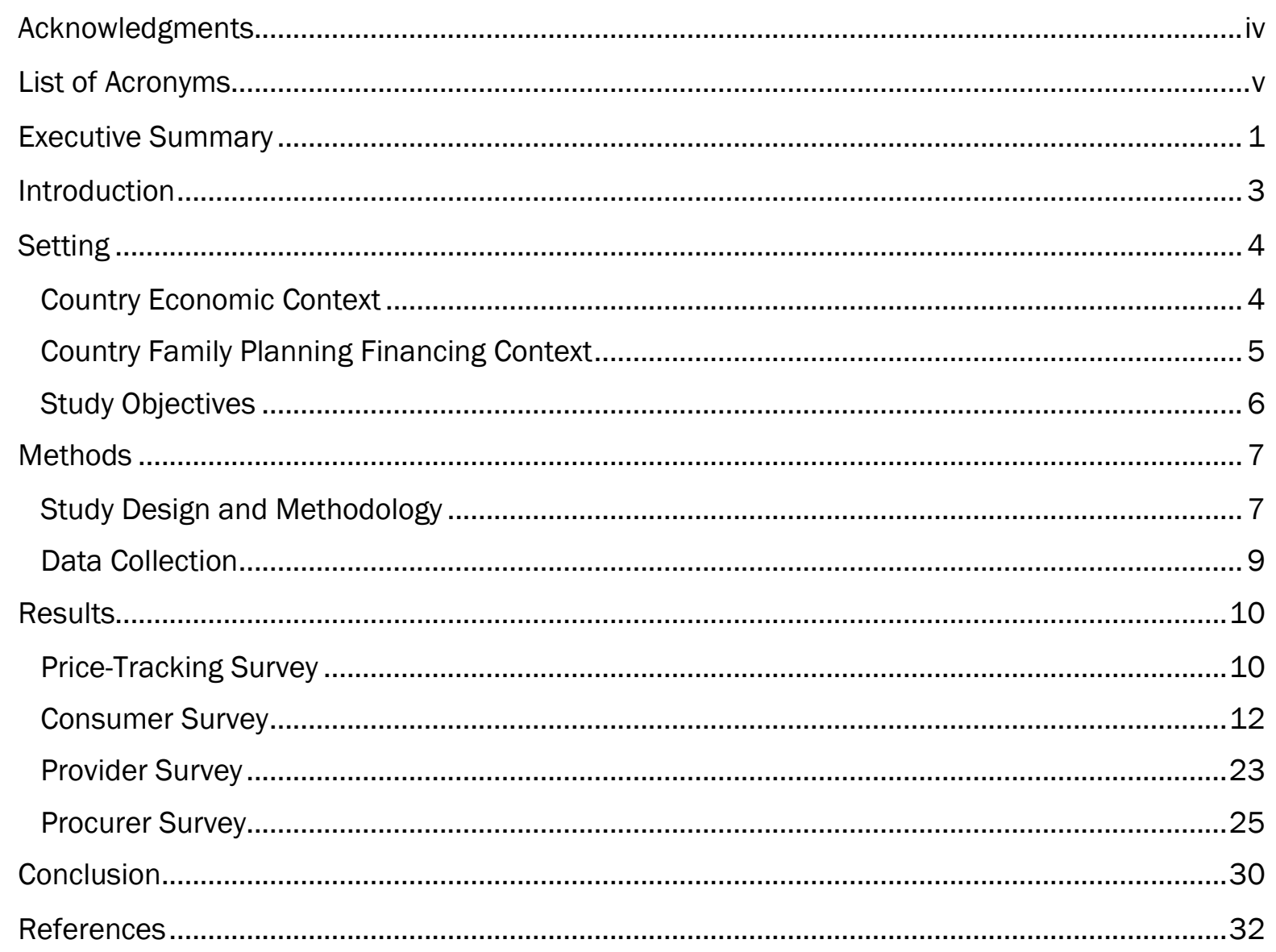




\section{Acknowledgments}

We acknowledge all stakeholders (government, private, and nonprofit agencies) and individuals (Dr. Bartilol Kigen [MOH], and Dr. Robert Ayisi and Dr. Sam Ochola [both from Nairobi County]) for facilitating the process of data collection in public, private, and NGO facilities within Nairobi County. The successful completion of the study would not have been possible without the dedication and support of study participants, health facility managers, service providers, and chemists and commercial companies that provide important reproductive health and family planning commodities. We would also like to thank the research assistants (Laura Kisivuli, Hellen Murugi, Esther Natembea, Laura Okhungu, Grace Rogena, and Maureen Yienya) for their keen interest and thoroughness in data collection. The providers who participated in the study from the initial acceptability sites (Ngoliba Health Center, Ruiru Sub-District Hospital, Thika Level 5 Referral Hospital, Igegania SubDistrict Hospital, Kirwara Sub-District Hospital, and Makadara Health Center) are also acknowledged for their dedication and hard work.

We also thank the Bill \& Melinda Gates Foundation for the financial support provided to conduct the study activities. The project was implemented by the Population Council in collaboration with the Ministry of Health in Kenya. 


\section{List of Acronyms}

$\begin{array}{ll}\text { BMGF } & \text { Bill \& Melinda Gates Foundation } \\ \text { CPI } & \text { Consumer Price Index } \\ \text { CPR } & \text { Contraceptive Prevalence Rate } \\ \text { COGS } & \text { Cost of Goods } \\ \text { CVM } & \text { Contingent Valuation Method } \\ \text { CVR } & \text { Contraceptive Vaginal Ring } \\ \text { FP } & \text { Family Planning } \\ \text { IUD } & \text { Intrauterine device } \\ \text { KDHS } & \text { Kenya Demographic and Health Survey } \\ \text { KEMSA } & \text { Kenya Medical Supplies Agency } \\ \text { KES } & \text { Kenya Shillings } \\ \text { LAM } & \text { Lactational Amenorrhea Method } \\ \text { NACOSTI } & \text { National Commission for Science, Technology, and Innovation } \\ \text { POP } & \text { Progestogen-Only Pills } \\ \text { PVR } & \text { Progesterone Vaginal Ring } \\ \text { TFR } & \text { Total Fertility Rate } \\ \text { TMA } & \text { Total Market Approach } \\ \text { RH } & \text { Reproductive Health } \\ \text { WTP } & \text { Willingness to Pay } \\ & \end{array}$





\section{Executive Summary}

Despite the progress made in reducing fertility and increasing the contraceptive prevalence rate (CPR) in Kenya, many women still experience a high unmet need for contraception. Part of the challenge in addressing current levels of unmet need is the limited use of contraception by women during the first 12 months postpartum. New methods are needed that offer greater ease of use, that are women-initiated, and that do not require significant health infrastructure or medical provider involvement for service delivery. One such method is the Progesterone Vaginal Ring (PVR), a userinitiated, reversible contraceptive that according to clinical trial data is safe and effective for breastfeeding women.

New product introduction strategies often suffer from lack of available market research and rely on hypothetical approaches to gauge consumer demand and provider readiness to offer services. The PVR, a new product in sub-Saharan Africa, faced such a challenge. For this reason, we determined that a study on Willingness to Pay (WTP) was necessary to estimate the effect of price on potential consumer demand for the method in Kenya.

The specific objectives of the study were to: (1) assess the willingness to pay for the PVR among potential users (women seeking family planning services at health facilities); (2) assess the willingness among health care providers (in public, private nonprofit, and private commercial sectors) to counsel on and offer the PVR to users; and (3) assess the willingness to procure the PVR among potential suppliers, including the government and donors. The study was conducted in Nairobi County between March and June 2015. The following are the main findings:

- Women seeking family planning services at public, private nonprofit, and private commercial facilities are willing to pay for the PVR if it is available. A significant proportion of women who visit the private commercial sector spend 50-199 Kenya shillings (KES) (US\$0.5-\$2) per month on family planning (FP) services and products. This implies that a market currently exists for family planning products through the private commercial sector.

- The majority of respondents were willing to pay a price equivalent to a three-month supply of Progestogen-only pills (POP) plus a 10\% increment on that price, with some variation across sectors. Respondents from public sector facilities were more sensitive to marginal price increments than those who were interviewed at private sector facilities.

- Nearly universally, health care providers (based in public, private nonprofit, and private commercial facilities) indicated that the PVR is an important option to include in the choice of methods, especially in light of the frequent and prolonged stock-out of Microlut contraceptive pills. They are willing to counsel and provide the PVR to users. Providers in the public and private nonprofit sectors suggested a median price of KES100 (US\$1) and those in the private commercial sector proposed a median price of KES200 (US $\$ 2$ ).

- Procurers are willing to procure the PVR and make it available through their distribution networks and outlets. They are willing to purchase the PVR at a much higher cost than what consumers had proposed. 
- There is potential for the private sector to play an active role in FP provision for the introduction of the PVR by serving customer segments based on their level of willingness to pay. Social marketing organizations and commercial players can ease the burden on public health expenditure while tapping into Kenya's growing economy, bringing consumers who have varying levels of ability to pay for FP products and services.

All key stakeholders (i.e., women, providers, and procurers in public, private nonprofit, and private commercial sectors) were interested and supportive of the one-year ring. All the individuals interviewed were willing to pay for the long-acting ring at higher costs than the PVR. The median price for the one-year ring varied across the sectors-KES100 (US\$1) in the public sector, KES400 (US\$4) in the private nonprofit sector, and KES500 (US\$5) in the private commercial sector. The study determines the ability of public sector consumers to afford FP products and the potential for serving them via private sector mechanisms.

In terms of utilization, the results generated will inform and guide the next steps about product introduction. Specifically, the findings of this study will be integrated with results from a market segmentation exercise conducted earlier to develop a pricing model for the PVR. The price will reflect not only the cost of goods sold (COGS) and costs of product introduction (e.g., training, educational material, marketing and branding, demand creation), but also the benefits to the health system (e.g., limited need for infrastructure and equipment, potential for multiple service outlets and health cadres). The results will also be useful to refine PVR market segmentation and tailor specific strategies for product introduction, including innovative financing approaches. 


\section{Introduction}

According to the Kenya Demographic and Health Survey (KDHS) 2014, Kenya's total fertility rate (TFR) is 3.9 births per woman (3.1 urban and 4.5 rural). It is important to point out that the TFR has declined from 8.1 births per woman in the mid-1970s to the current level of 3.9 births. The contraceptive prevalence rate (CPR) is usually defined as the percentage of currently married women using any contraceptive method. Slightly more than half of currently married women (58\%) are using some method of contraception. Among currently married women, modern methods of contraception are more commonly used (53\%) than traditional methods (5\%). Of the modern methods, injectables are the most widely used (26\%), followed by implants (10\%) and the pill (8\%). The calendar rhythm method is the most popular traditional method used (4\%).

Contraceptive prevalence increases dramatically with education. Near one-fifth (18\%) of currently married women with no education use a method, while more than half of women with at least some primaryschool level of education use contraception. Women with three to four children are the most likely to use contraception (66\%). Currently married women in the Central region have the highest CPR (73\%), followed by women in the Eastern region (70\%). Contraceptive use is lowest in the North Eastern region (3\%). Table 1 provides information on family planning (FP) services (including sterilization) and how frequently these are offered, by facility type and managing authority (Kenya Service Provision Assessment [KSPA] 2010).

TABLE 1 Background characteristics

\begin{tabular}{|c|c|c|c|c|c|c|}
\hline & $\begin{array}{l}\text { Modern FP } \\
\text { Method } \\
\text { Offered (\%) }\end{array}$ & $\begin{array}{l}\text { Counseling on } \\
\text { Natural Method } \\
\text { Offered (\%) }\end{array}$ & $\begin{array}{c}\text { Temporary FP } \\
\text { Method Offered } \\
(\%)\end{array}$ & $\begin{array}{c}\text { Male or Female } \\
\text { Sterilization } \\
\text { Offered }(\%)\end{array}$ & $\begin{array}{c}\text { Male or Female } \\
\text { Sterilization } \\
\text { Provided (\%) }\end{array}$ & $\begin{array}{l}\text { Number of } \\
\text { Facilities }\end{array}$ \\
\hline \multicolumn{7}{|c|}{ Type of Facilities } \\
\hline Hospital & 85 & 75 & 91 & 67 & 46 & 51 \\
\hline Health center & 83 & 64 & 86 & 33 & 20 & 80 \\
\hline Maternity & 88 & 63 & 88 & 47 & 31 & 17 \\
\hline Clinic & 80 & 44 & 81 & 18 & 3 & 203 \\
\hline Dispensary & 89 & 59 & 94 & 22 & 2 & 340 \\
\hline \multicolumn{7}{|c|}{ Managing Authority } \\
\hline Government & 96 & 64 & 97 & 33 & 11 & 344 \\
\hline NGO & 89 & 36 & 89 & 24 & 7 & 22 \\
\hline $\begin{array}{l}\text { Private } \\
\text { (for profit) }\end{array}$ & 84 & 46 & 84 & 21 & 7 & 236 \\
\hline $\begin{array}{l}\text { Faith-based } \\
\text { organization }\end{array}$ & 44 & 58 & 69 & 12 & 3 & 88 \\
\hline
\end{tabular}


Despite the progress made in reducing fertility and increasing the contraception use prevalence rate, many women still experience a high unmet need for contraception. Part of the challenge in addressing current levels of unmet need is the limited use of contraception by women during the first 12 months postpartum, and the high discontinuation rates with about half of all users abandoning their methods 6 months after adoption. New methods are needed that offer greater ease of use, are women-initiated, and do not require significant health infrastructure or medical provider involvement for service delivery. One such method is the Progesterone Vaginal Ring (PVR), a user-initiated, reversible contraceptive that, according to clinical trial data, is safe and effective for breastfeeding women.

The Progesterone Vaginal Ring (PVR) is designed exclusively for addressing the postpartum family planning needs of breastfeeding women. While the PVR is already being used by women in nine countries in Latin America, women in sub-Saharan Africa, where breastfeeding is almost universal, have no access to this technology. To expand access in this region, the Population Council, with funding from the Bill \& Melinda Gates Foundation (BMGF) and the United States Agency for International Development (USAID), conducted various pre-introductory activities in sub-Saharan Africa where women practice prolonged lactation and also have a high unmet need for postpartum family planning of up to $65 \%$ in many countries (Sonalkar et al. 2013). The assessment of "Willingness to Pay" (WTP) for the PVR was conducted to understand the economic factors that may determine its uptake and use. In the case of contraceptives, WTP informs about the value that people attach to the benefits of various contraceptives, especially their willingness and intention to purchase them at various assigned hypothetical prices.

Ever-increasing changes in the funding landscape have prompted governments to explore "total market" solutions. The Total Market Approach (TMA) identifies specific roles for the public and private sectors in meeting the FP needs of the population. Specifically, it focuses on ensuring that free or subsidized contraceptives are available to the needy and poor, and social marketing channels and other private commercial sales of contraceptives cater to those who are able to pay. This approach can help ensure equity and sustainability of products and services over time and also manage funding shortfalls. Using TMA as a guiding design principle, this study provides new knowledge on the maximum amount of money that consumers are willing to pay for the PVR and a related ring, the oneyear contraceptive vaginal ring (CVR), from various service sectors (public, private nonprofit, and private commercial).

\section{Setting}

\section{COUNTRY ECONOMIC CONTEXT}

According to the Kenya National Bureau of Statistics (KNBS 2015), Kenya's economic growth was $4.9 \%$ in the first quarter of 2015 compared with $4.7 \%$ in the same period in 2014 . Categorized as a lower-middle-income country, with a population of close to 45 million people, Kenya is among the promising emerging economies in East Africa. The business environment has significantly improved in Kenya in recent years with investments in infrastructure, agriculture, manufacturing, and other industries. The construction of a new railway line, initially to run from Mombasa to Nairobi, is scheduled for completion in mid-2017. To achieve strong and sustainable economic growth and 
poverty reduction, the government is focusing on reducing the cost of doing business and encouraging private sector innovation and entrepreneurship as well as business expansion.

The per capita household final consumption expenditure in Kenya (the market value of all goods and services, including durable products such as cars, washing machines, and home computers purchased by households) has been on an upward trend since 2014, reaching US $\$ 517,{ }^{1}$ while the gross national income per capita has risen steadily from US\$1,040 in 2011 to US\$1,290 (current US\$). In 2013, private health expenditure (\% of GDP), which includes direct household (out-of-pocket) spending, private insurance, and charitable donations by private corporations, was 2.6 , staying the same since 2011. Public health expenditure ${ }^{2}$ (as \% of GDP) was 1.9 in 2013 and has remained close to this level since 2011. Total health expenditure ${ }^{3}$ (\% of GDP) has risen slightly from 4.3 in 2011 to 4.5 in 2013. Kenya's Gross Domestic Product (GDP) is estimated at US\$70 billion (2015 estimate) with an estimated GDP per capita of US\$1,588 (for 2015) at current prices.

TABLE 2 Cost of living snapshot in Nairobi, Kenya

\begin{tabular}{l|c|c}
\hline \multicolumn{1}{c|}{ Commodity } & Quantity & Average Price (US\$) \\
\hline Milk & 1 gallon & 3.4 \\
\hline Bread & 1 pound & 0.5 \\
\hline Eggs & 1 dozen & 1.4 \\
\hline Onion & 1 pound & 0.4 \\
\hline Beef & 1 pound & 2.1 \\
\hline Gasoline & 1 gallon & 1.7 \\
\hline
\end{tabular}

Source: www.numbeo.com.

The average annual Consumer Price Index (CPI) increased from 140.1 in 2013 to 149.7 in 2014. This resulted in a modest increase in the rate of inflation and attributed to increases in the cost of several food and nonfood items, which outweighed notable falls in the cost of electricity and petroleum products including petrol, diesel, and kerosene. The inflation rate maintained its singledigit level, rising from $5.7 \%$ in 2013 to $6.9 \%$ in $2014 .{ }^{4}$ With its competitive manufacturing sector driving new job creation and exports, Kenya is poised for successful economic growth.

\section{COUNTRY FAMILY PLANNING FINANCING CONTEXT}

In Kenya, the public and private sectors (including households) are the primary sources of reproductive health $(\mathrm{RH})$ financing. ${ }^{5}$ Funding shortages have encouraged exploration of innovative financing models and coordinated action from the private sector, including social marketing organizations. The role of the private sector is largely underutilized and the public sector continues to take on a dominant role in providing FP products and services. The major sources of modern

1 Data reported in constant 2005 US dollars. Sources: World Bank national accounts data and OECD National Accounts data files.

2 Public health expenditure consists of recurrent and capital spending from government (central and local) budgets, external borrowings and grants (including donations from international agencies and nongovernmental organizations), and social (or compulsory) health insurance funds.

3 Total health expenditure is the sum of public and private health expenditure. It covers the provision of health services (preventive and curative), family planning activities, nutrition activities, and emergency aid designated for health, but does not include provision of water and sanitation.

4 Current World Bank data (2015).

5 Republic of Kenya (2011), Kenya National Health Accounts 2009/10. 
contraceptives for women are public health facilities (57\%) and private health facilities (a substantial 36\%). Other sources, such as mobile clinics, community-based distribution, and shops, comprise the remaining six percent (KNBS and ICF Macro 2010). Kenya's FP market provides a variety of methods-hormonal, intrauterine devices (IUDs), surgical, barrier, lactational amenorrhea method (LAM), and fertility awareness (DRH and MOPHS 2010). Injectables, priced slightly less than US\$1 per unit, are clearly the most popular. Among women who pay for their method, median cost is highest for surgical contraception, at about US $\$ 30$. Available methods for postpartum women include LAM, IUCDs, sterilization, progestogen-only pills, injectables, and condoms, with injectables again being the most common (Gebreselassie, Rutstein, and Mishra 2008; DRH and MOPHS 2010).

In collaboration with development partners, the Ministry of Public Health and Sanitation (MOPHS) and the Ministry of Medical Services (MOMS) developed a Costed Implementation Plan (CIP) for FP following the guidelines in the National Reproductive Health Policy 2007 and the National RH Strategy 2009-2015. Interventions and activities to promote CPR that will increase as per FP20206 commitments are outlined in CIP. The key thematic areas identified in CIP are human resources, integration, commodity security, youth, advocacy, and demand creation. Other notable interventions include the Tupange project, ${ }^{7}$ funded by BMGF under its Urban Health Reproductive Initiative (URHI), which aims to increase CPR by 20 percentage points in selected project areas in Kakamega, Kisumu, Machakos, Mombasa, and Nairobi. Expanding the role of the private sector will not only accelerate Kenya's progress toward the FP2020 goals but also enable the Kenyan government to redirect investment on other health priorities.

\section{STUDY OBJECTIVES}

The overall goal of the study was to generate evidence on the potential market dynamics that will inform the introduction of a new contraceptive method in sub-Saharan Africa. The specific objectives of the study were to:

1) Obtain reliable estimate of consumers' demand for the PVR in Kenya by studying the effect of price on demand;

2) Assess the "Willingness to Provide" by family planning providers and "Willingness to Procure" by procurers;

3) Facilitate evidence-based pricing for the PVR in the three sectors of interest-public, private nonprofit, and private commercial; and

4) Explore respondents' WTP for future vaginal rings (including long-acting, reversible options for nonbreastfeeding women) to assess potential demand and design access strategies.

6 FP2020: http://www.familyplanning2020.org/.

7 Tupange Project: http://www.tupange.or.ke/. 


\section{Methods}

\section{STUDY DESIGN AND METHODOLOGY}

A cross-sectional study was conducted in three countries in sub-Saharan Africa (Kenya, Nigeria, and Senegal). The study used a multidimensional and multisectoral approach, which examined willingness to pay for the PVR in the three countries. These approaches included:

Stakeholder-driven approach to WTP: We identified three actors in the PVR WTP assessment landscapepotential consumers, providers, and procurers. We explored the three dimensions of WTP-WT Pay, WT Provide, and WT Procure-by incorporating the voices of these three stakeholders in the data collection tools.

Sector-driven approach to WTP: Using the guiding principles of improved access, efficient use of public resources, and increased equity, we explored a potential total market model for the PVR by exploring the views and expectations of different sectors that serve FP customers-the public, private nonprofit, and private commercial sectors.

Table 3 summarizes the survey tools and methodology used in this WTP study including specific survey instruments that were designed for target respondents.

TABLE 3 Study design, methodology, and scope

\begin{tabular}{l|l|l}
\hline Stakeholder & Survey Instrument & Target Respondents \\
\hline Consumers & $\begin{array}{l}\text { a) WT Pay Survey } \\
\text { b) Price-Tracking Survey }\end{array}$ & $\begin{array}{l}\text { a) Potential consumers (women aged 18-49 years old) } \\
\text { b) Pharmacists; facilities in charge at social marketing } \\
\text { outlets; and public FP clinics }\end{array}$ \\
\hline Providers & WT Provide Survey & $\begin{array}{l}\text { FP service providers and members of professional } \\
\text { associations, such as pharmacists, ob/gyns, midwives, } \\
\text { nurses, other providers }\end{array}$ \\
\hline Procurers & WT Procure Survey & $\begin{array}{l}\text { MOH, USAID Mission, UNFPA, MSI/Kenya, and large } \\
\text { pharma distributors }\end{array}$ \\
\hline
\end{tabular}

The WTP study was conducted in Nairobi County because the county has the highest concentration of urban, educated women from more wealthy households. Since FP is provided free of charge in Kenya, it is important to know if there is a segment of the population that will be able to pay for the ring-either subsidized or full price-especially since there is a deliberate global effort to have all economies move to a total market approach. In addition, Nairobi also has the highest concentration of health care facilities and agencies involved in procuring FP commodities. Study populations were:

a) Numbering close to 400 women (397) aged 18-49 years seeking family planning services at selected health facilities in Nairobi County. The total number of participants was distributed as follows: public (278); private nonprofit (14) and private commercial (105). Questions on consumer characteristics were included to gauge household expenses, family income, and discretionary expenses, which will determine "ability to pay" for the PVR. Questionnaires were designed using the standard format for the Contingent Valuation Methodology (CVM), which has three sections: (1) socioeconomic background; (2) knowledge and need for postpartum FP; and (3) WTP for the PVR. 
b) Family planning service providers aged 18 years and above in selected health facilities. We interviewed 10 providers from the initial pilot sites and 50 other providers drawn from health facilities that were not part of the PVR pilot study. The providers were asked qualitative questions to gauge their willingness to provide the PVR as part of the existing FP method mix in their health facilities.

In addition, they were asked to estimate the maximum amount that should be charged (if any) for providing the PVR. Respondents included randomly selected FP providers such as gynecologists, nurses and midwives, clinical officers, and pharmacists.

c) In charge of selected health facilities. A total of 50 health facilities were assessed in the pricetracking survey. Out of this total, 17 were from the public sector, 6 were from the private nonprofit sector, and 27 were from the private commercial sector.

d) Representatives of government, social marketing, and donor agencies involved in procuring FP commodities. Out of 23 procurers who were interviewed, 3 were from the public sector; 8 were from the private nonprofit sector, and 12 were from private commercial sector.

e) Procurers were asked to provide the price list of procured FP commodities and their assessment of a reasonable price estimate for procuring the PVR, to assess their "willingness to procure" it. After being provided with a detailed description of the PVR, procurers were asked their willingness to buy the PVR for a modest starter price and then to state their maximum willingness to pay to procure the PVR.

In conducting the survey, the following procedures were followed:

Since the PVR is a new product, respondents were shown a product sample and provided a full description, including the ring's use and benefits. Examples were given to draw connections with comparable products, such as progestogen-only pills.

To reduce bias, user interest was ascertained by providing an option to rate interest in the PVR before starting the survey. Uninterested respondents were not interviewed.

Different WTP price references for the PVR were used depending on the type of sector where clients who were interviewed had gone to seek services. For instance, in the public sector, data was captured on the maximum service fee that the potential user was willing to pay for the PVR.

In the private nonprofit sector, the WTP measure was the subsidized price for the PVR that the potential user was willing to pay. In the private commercial sector, the WTP measure referred to the maximum selling price the consumer was willing to pay.

We used the current price of a three-month supply of Progestogen-only pills before determining the hypothetical price ranges we tested. Questions for respondents started with a modest price assumption for the PVR of KES90 (US\$0.90) in the public sector; KES120 (US\$1.20) in the private nonprofit sector, and KES150 (US\$1.50) in the private commercial sector. 
We ended the interview with two open-ended questions: (1) We asked the maximum price the respondent was willing to pay for the PVR independent of the previously mentioned prices; (2) We sought to know the possible action the respondent would take if the price were found to be too high. See Figure 1 for the sequence of questions asked, which were adapted from Foreit and Foreit (2001).

FIGURE 1 CONSUMER SURVEY: BIDDING GAME MODEL

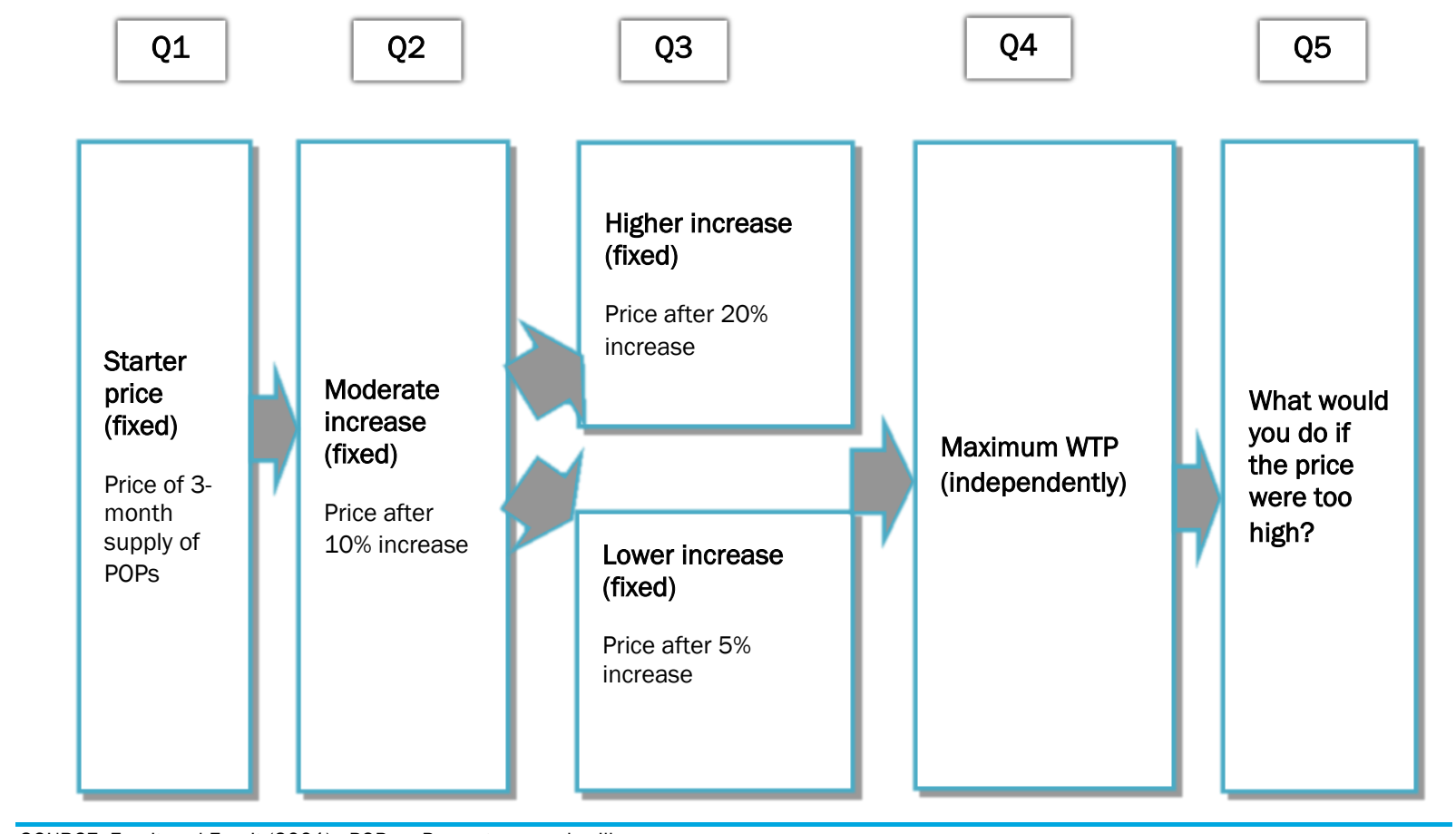

SOURCE: Foreit and Foreit (2001). POPs = Progestogen-only pills.

\section{DATA COLLECTION}

The Ethics and Research Committee (ERC) of Kenyatta National Hospital, University of Nairobi granted ethical clearance for the study. The National Commission for Science, Technology, and Innovation (NACOSTI) granted the research permit for the study.

The data collected were manually entered into EPI DATA. A direct estimation model for calculating the demand curve as described in the WTP study manual was used (Foreit and Foreit 2001). All responses with a maximum WTP price were checked for internal consistency. (The maximum price stated had to be equal to or higher than the highest price accepted. Demand curves were derived from frequency distributions of the maximum WTP price.) The WTP technique described here includes the assumption that only the price varies and all other factors remain constant. 


\section{Results}

The WTP study was structured into four components: namely a price-tracking survey, interviews with potential consumers, and a survey among providers and procurers. Table 4 shows the sample sizes achieved by study components and sectors surveyed.

TABLE 4 Sample sizes achieved by study component and sector

\begin{tabular}{|c|c|c|c|c|c|c|c|c|}
\hline \multirow[t]{2}{*}{ Type of Method } & \multicolumn{2}{|c|}{ Public Sector } & \multicolumn{2}{|c|}{$\begin{array}{l}\text { Private Nonprofit } \\
\text { Sector }\end{array}$} & \multicolumn{2}{|c|}{$\begin{array}{c}\text { Private Commercial } \\
\text { Sector }\end{array}$} & \multirow[t]{2}{*}{$\mathrm{N}$} & \multirow[t]{2}{*}{ Percentage } \\
\hline & $n$ & $\%$ & $n$ & $\%$ & $\mathrm{n}$ & $\%$ & & \\
\hline Price-Tracking & 17 & 34 & 6 & 12 & 27 & 54 & 50 & 100 \\
\hline Consumers & 278 & 70 & 14 & 4 & 105 & 26 & 397 & 100 \\
\hline Providers & 17 & 27 & 6 & 9 & 41 & 64 & 64 & 100 \\
\hline Procurers & 3 & 13 & 8 & 35 & 12 & 52 & 23 & 100 \\
\hline
\end{tabular}

\section{PRICE-TRACKING SURVEY}

As shown in Table 4, 17 public sector facilities, 6 private nonprofit facilities, and 27 private commercial facilities participated in the survey. Health providers in charge of facilities (doctors, nurses, clinical officers), or pharmacists or other pharmacy staff in the case of chemists, were asked to name contraceptives available in their respective facilities and the corresponding price(s) for each category of contraceptives on the day of the interview.

Contraceptives that were in stock most of the time were injectables (Depo-Provera or DMPA), implants (Jadelle), pills (Progestogen-only pills or Microlut, combined oral contraceptives or Femiplan), and male condoms. Others were emergency contraceptive pills and copper intrauterine devices (IUDs).

Respondents in public health facilities pointed out that breastfeeding women in the postpartum period were facing a challenge in accessing a suitable FP method due to frequent and prolonged stock-out of Microlut.

The majority of respondents in public sector facilities indicated that they dispensed or issued contraceptives to their clients free of charge as per government policy. ${ }^{8}$ However, respondents in the private nonprofit and private commercial sectors said that they levied a fee for various types of contraceptives even if the source of the contraceptives was the Kenya Medical Supplies Agency (KEMSA), which is a government institution under the Ministry of Health.

As shown in Table 5, the median price of injectables (or DMPA) was KES100 (US\$1) across the private nonprofit and private commercial sectors. The median price for pills was much lower in the private nonprofit sector at KES20 (US\$0.2). The cost of implants was much higher in the private commercial sector at KES1,000 (US\$10). Most of the respondents acknowledged that the price of contraceptives shown in Table 5 included a markup to cover labor costs and other recurrent costs at the facility or within

\footnotetext{
8 Ministry of Health, Republic of Kenya (2000): “Family Planning and Reproductive Health Commodities in Kenya Background Information for Policymakers."
} 
the program or management chain that was responsible for running the facility or chemist(s). Most of the respondents were not aware of the exact figure for the markup. They indicated that the business owners knew the percentage of markup or taxation. This finding is similar in other countries (Nigeria and Senegal) as well.

TABLE 5 Median prices of commonly available contraceptives by sector in Kenya

\begin{tabular}{|c|c|c|c|}
\hline & Brand & Median Price (KES) & Median Price (USD) \\
\hline \multicolumn{4}{|c|}{ Private Nonprofit Sector } \\
\hline Injectables & Depo-Provera & 100 & 1 \\
\hline Implants & Jadelle & 400 & 4 \\
\hline Pills & Microlut & 20 & 0.2 \\
\hline \multicolumn{4}{|c|}{ Private Commercial Sector } \\
\hline Injectables & Depo-Provera & 100 & 1 \\
\hline Implants & Jadelle & 1,000 & 10 \\
\hline Pills & Microlut & 100 & 1 \\
\hline
\end{tabular}

\section{Frequency of Fee Structure Changes}

Regarding the frequency of changes to the fee structure for contraceptive methods, a significant proportion of respondents in the private nonprofit and private commercial sectors said that their fee structure does not change very often and remains relatively stable for extended periods of time. A few of them said that the fees did change on a weekly basis. Others said that the fees could even change on a daily basis. Four of the respondents said that they changed the fees on a quarterly basis. Three respondents said that they changed the fees semi-annually. The rest of the respondents said that the change in fees levied was dependent on the manufacturers' conditions, including the going price as well as the supply and demand for pharmaceuticals in general and for contraceptives in particular.

\section{Frequency of Contraceptive Stock Delivery}

The majority of respondents said that they received contraceptive stocks in less than a month. Some mentioned quarterly supply, especially those who receive stocks directly from government stores (i.e., the Kenya Medical Supplies Agency). A smaller proportion of respondents mentioned that they received their stocks semi-annually or annually.

\section{General Comments and Observations of Respondents}

At the end of the interview, the interviewer provided an opportunity for respondents to ask questions or offer observations regarding the interview. The majority of respondents asked whether staff in the private sector would be considered for training on the PVR. Others wanted to know whether the PVR would replace Microlut, which has not been in stock for quite some time. Respondents raised the issue of hygiene and potential infection if proper hygiene measures are not taken with the PVR. Some respondents asked whether men would be allowed to purchase the PVR for their partners. Others pointed out that FP commodities are free of charge in government health facilities and asked whether the PVR will also be free of charge in those facilities. Some observed that the PVR would expand method mix, especially for women in the postpartum period. 


\section{CONSUMER SURVEY}

\section{Demographic Characteristics of Study Participants by Sector}

TABLE 6 Demographic characteristics of study participants by sector

\begin{tabular}{|c|c|c|c|}
\hline Variable & $\begin{array}{l}\text { Public Sector } \\
\text { (n=278) }\end{array}$ & $\begin{array}{l}\text { Private Nonprofit Sector } \\
(n=14)\end{array}$ & $\begin{array}{l}\text { Private Commercial Sector } \\
\qquad(n=105)\end{array}$ \\
\hline & $\%$ & $\%$ & $\%$ \\
\hline \multicolumn{4}{|l|}{ Age } \\
\hline $15-19$ & 4 & 0 & 1 \\
\hline $20-24$ & 41 & 43 & 26 \\
\hline $25-29$ & 35 & 21 & 43 \\
\hline $30-34$ & 14 & 7 & 18 \\
\hline$>35$ & 7 & 29 & 12 \\
\hline \multicolumn{4}{|l|}{ Highest Level of Education } \\
\hline None, never attended & 0 & 0 & 2 \\
\hline Primary & 37 & 43 & 14 \\
\hline Secondary & 46 & 36 & 27 \\
\hline College/graduate & 17 & 43 & 57 \\
\hline \multicolumn{4}{|l|}{ Marital Status } \\
\hline Married & 90 & 64 & 83 \\
\hline Not currently married & 10 & 36 & 17 \\
\hline \multicolumn{4}{|l|}{ Employment Status } \\
\hline Housework/not working & 45 & 29 & 27 \\
\hline Business & 20 & 29 & 22 \\
\hline Government & 1 & 0 & 11 \\
\hline Manual/temporary work & 10 & 0 & 6 \\
\hline Student & 2 & 21 & 8 \\
\hline Other & 22 & 21 & 27 \\
\hline \multicolumn{4}{|l|}{ Spouse Employment Status } \\
\hline Business & 28 & 0 & 33 \\
\hline Government & 10 & 22 & 27 \\
\hline Manual/temporary work & 30 & 34 & 11 \\
\hline Other & 32 & 44 & 29 \\
\hline
\end{tabular}

As shown in Table 6, the majority of the clients who were interviewed in the public sector (41\%) and private nonprofit sector (43\%) were between 20 and 24 years of age. The majority of those interviewed from the private sector were between 25 and 29 years of age. A majority (46\%) of those interviewed in the public sector had secondary education, $43 \%$ of those interviewed in the private nonprofit sector had both primary and college/graduate education, while $57 \%$ of those interviewed from the private commercial sector had college/graduate education. Most of the clients interviewed in the public (90\%) and private commercial (83\%) sectors were married, compared to $64 \%$ in the private nonprofit sector. 
Overall, the spouses of the clients who were interviewed were twice as likely to be engaged in business or in manual/temporary work compared to the women themselves. None of the respondents and partners who were interviewed at the private nonprofit health facilities cited the government as the institution or place where they are employed.

These findings contrast with those obtained from respondents who sought services from private for-profit health facilities, where $27 \%$ of spouses cited the government as a place where they are employed. In summary, respondents who were interviewed in the private commercial sector presented a higher socioeconomic profile.

\section{Socioeconomic Characteristics of Study Participants by Sector}

TABLE 7a Sociodemographic characteristics of study participants by sector

\begin{tabular}{|c|c|c|c|}
\hline Variable & $\begin{array}{l}\text { Public Sector } \\
(n=278)\end{array}$ & $\begin{array}{l}\text { Private Nonprofit } \\
\text { Sector }(n=14)\end{array}$ & $\begin{array}{l}\text { Private Commercial } \\
\text { Sector }(n=105)\end{array}$ \\
\hline & $\%$ & $\%$ & $\%$ \\
\hline \multicolumn{4}{|l|}{ Number of Children } \\
\hline 1 & 48 & 27 & 28 \\
\hline 2 & 34 & 18 & 50 \\
\hline 3 & 14 & 55 & 14 \\
\hline $4+$ & 5 & 0 & 8 \\
\hline \multicolumn{4}{|l|}{ Family Planning Use } \\
\hline Not using and does not intend to use in the future & 4 & 7 & 6 \\
\hline Yes, currently using & 82 & 71 & 79 \\
\hline Not currently using, but intends to use in the future & 14 & 14 & 15 \\
\hline \multicolumn{4}{|l|}{ Monthly FP Expense (KES) } \\
\hline$<50$ & 29 & 0 & 1 \\
\hline $50-199$ & 50 & 33 & 58 \\
\hline $200-499$ & 4 & 33 & 10 \\
\hline 500-999 & 7 & 17 & 16 \\
\hline$>1,000$ & 11 & 17 & 15 \\
\hline \multicolumn{4}{|l|}{ Household Items } \\
\hline Television & 80 & 86 & 97 \\
\hline Refrigerator & 13 & 14 & 57 \\
\hline Vehicle & 7 & 14 & 26 \\
\hline Mobile & 99 & 93 & 100 \\
\hline Radio & 82 & 86 & 87 \\
\hline
\end{tabular}

The socioeconomic characteristics of study participants addressed in this section are: a) number of children; b) family planning use; c) monthly FP expenditure; and d) household items (Table 7a). Nearly half of the women (48\%) who were interviewed in the public sector had given birth to one child.

Nearly $55 \%$ of those interviewed in the private nonprofit sector had at least 3 children, while $50 \%$ of those interviewed from the private commercial sector had 2 children. The majority of the women were current users of FP services. As expected, most of those who paid for FP services were interviewed at the private commercial sector facilities with the majority spending between KES 50-199 (US\$0.5-\$2) per month. 
A much higher proportion of women (58\%) who were interviewed at the private sector commercial facilities spent between KES50-199 (US\$0.5-\$2) per month on FP services compared to those who sought services in the public and nonprofit sectors.

The majority of clients interviewed at the private commercial sector facilities possessed most of the household items, such as televisions, compared to those who sought services from the public and nonprofit health facilities. Those clients who sought services from the public facilities had the least amount of household items, followed by the private nonprofit health facilities. No differences were noted in mobile phone ownership across the three sectors, indicating that the level of discretionary spending on mobile phone use may be similar. This also suggests that mobile services may be useful in PVR client counseling or follow-up.

\section{Visits to Hair Salon, Monthly Expenditure, and Income Level}

TABLE 7b Sociodemographic characteristics of study participants by sector

\begin{tabular}{lccc}
\hline Variable & $\begin{array}{c}\text { Public Sector } \\
(\mathrm{n}=278)\end{array}$ & $\begin{array}{c}\text { Private Nonprofit } \\
\text { Sector }(\mathrm{n}=14)\end{array}$ & $\begin{array}{c}\text { Private Commercial } \\
\text { Sector }(\mathrm{n}=105)\end{array}$ \\
\hline \multicolumn{1}{l}{ Salon Visits } & $\%$ & $\%$ & $\%$ \\
$\quad$ Weekly & 5 & 0 & 11 \\
Monthly & 65 & 79 & 64 \\
Other & 19 & 21 & 16 \\
$\quad$ Do not know & 11 & 0.0 & 9 \\
Monthly Expenditure (KES) & & & 69 \\
$<50,000$ & 97 & 84 & 19 \\
$50,000-100,000$ & 3 & 8 & 12 \\
$>100,000$ & 0 & 8 & 3 \\
Income Level (KES) & & & 74 \\
Low (<10,000) & 13 & 27 & 23 \\
Medium (10,000-100,000) & 84 & 73 & 0 \\
High $(>100,000)$ & 3 & 0 & \\
\hline
\end{tabular}

The average monthly expenditure for the majority of clients (97\%) who sought services from the public sector was less than KES50,000 (US\$500). Approximately 12\% of the clients who sought services from the private commercial sectors spent over KES100,000 (US\$1,000) per month. None of the clients spent more than KES100,000 (US\$1,000) to seek services in the public sector. Approximately $84 \%$ of the clients who sought services from the public sector had a monthly income that ranged from KES10,000100,000 , whereas $12 \%$ of the clients who sought services from the private or commercial sector facilities spent over KES100,000 (US \$1,000). None of the clients interviewed while seeking services from the private nonprofit sector had a monthly total income of over KES100,000 (US \$1,000). (Table 7b.) These data confirm that respondents from the private sector are economically more advantaged than those who were interviewed at public sector facilities. Furthermore, a comparison of the two sectors suggests that the public sector may be serving some who could potentially pay for services and should ideally be seeking services in the private sector. 


\section{Consumer Interest in Purchasing the PVR}

As shown in Table 8, potential consumers indicated that they would be interested in purchasing the PVR if it becomes available in the future.

TABLE 8 Consumer interest in purchasing the PVR by sector

\begin{tabular}{|c|c|c|c|c|c|c|c|c|}
\hline \multirow[t]{2}{*}{ Variable } & \multicolumn{2}{|c|}{$\begin{array}{l}\text { Public Sector } \\
\quad(n=278)\end{array}$} & \multicolumn{2}{|c|}{$\begin{array}{l}\text { Private Nonprofit } \\
\text { Sector }(n=14)\end{array}$} & \multicolumn{2}{|c|}{$\begin{array}{l}\text { Private Commercial } \\
\text { Sector }(n=105)\end{array}$} & \multicolumn{2}{|c|}{ Total } \\
\hline & $n$ & $\%$ & $n$ & $\%$ & $n$ & $\%$ & $n$ & $\%$ \\
\hline $\begin{array}{l}\text { Yes, I would be interested in } \\
\text { purchasing the PVR }\end{array}$ & 192 & 69 & 9 & 64 & 68 & 65 & 269 & 68 \\
\hline $\begin{array}{l}\text { No, I would not be interested } \\
\text { in purchasing the PVR }\end{array}$ & 86 & 31 & 5 & 36 & 37 & 35 & 128 & 32 \\
\hline Total & 278 & 100 & 14 & 100 & 105 & 100 & 397 & 100 \\
\hline
\end{tabular}

As shown in Table 8, out of the 397 respondents interviewed, 269 (68\%) were willing to purchase the PVR if it were made available in future. The responses were similar across all sectors (public, private nonprofit, and private commercial).

\section{Reference Prices for Willingness to Pay (WTP) by Sector}

The reference WTP prices for the PVR by sector are shown in Table 9.

TABLE 9 Reference WTP Prices for the PVR by Sector

\begin{tabular}{l|c|c|c}
\hline Provider Profile & Public Sector (KES) & $\begin{array}{c}\text { Private Nonprofit Sector } \\
(\text { KES }\end{array}$ & $\begin{array}{c}\text { Private Commercial } \\
\text { Sector (KES) }\end{array}$ \\
\hline Starter price & $90($ US $\$ 0.90)$ & $120($ US $\$ 1.20)$ & $150($ US $\$ 1.50)$ \\
Price after 10\% increase & $100($ US $\$ 1.00)$ & $130($ US $\$ 1.30)$ & $165($ US $\$ 1.65)$ \\
Price after 20\% increase & $110($ US $\$ 1.10)$ & $145($ US $\$ 1.45)$ & $180($ US $\$ 1.80)$ \\
Price after 5\% decrease & $85($ US $\$ 0.85)$ & $115($ US $\$ 1.15)$ & $145($ US $\$ 1.45)$ \\
\hline
\end{tabular}

\section{WTP for the PVR}

Respondents were asked a series of questions regarding their willingness to pay for the PVR at the starter price, at a $10 \%$ increment, and at a $20 \%$ increment. The responses to the respective questions are outlined in Table 10.

TABLE 10 WTP for the PVR by starter price, level of increment, and sector

\begin{tabular}{lcccccccc}
\hline & \multicolumn{2}{c}{$\begin{array}{c}\text { Public Sector } \\
(\mathrm{n}=278)\end{array}$} & $\begin{array}{c}\text { Private Nonprofit } \\
\text { Sector }(\mathrm{n}=14)\end{array}$ & $\begin{array}{c}\text { Private Commercial } \\
\text { Sector }(\mathrm{n}=105)\end{array}$ & Total \\
\hline & $\mathrm{n}$ & $\%$ & $\mathrm{n}$ & $\%$ & $\mathrm{n}$ & $\%$ & $\mathrm{n}$ & $\%$ \\
\hline $\begin{array}{l}\text { Respondents interested } \\
\text { in the PVR }\end{array}$ & 192 & 69 & 9 & 64 & 69 & 66 & 270 & 68 \\
Starter price & 164 & 85 & 9 & 100 & 68 & 98 & 241 & 89 \\
$10 \%$ increment & 147 & 77 & 9 & 100 & 57 & 83 & 213 & 79 \\
$20 \%$ increment & 86 & 45 & 5 & 56 & 52 & 75 & 143 & 53 \\
\hline
\end{tabular}


As seen in Table 10, 68\% were interested in the PVR with little difference across the sectors. The demand for the PVR at the starter price equaled 89\%, with variations across the sectors. Most of those interviewed in the public sector (85\%) were willing to pay at a starter price of KES90 (US\$0.90) and all those interviewed in the private nonprofit sector were willing to pay at a starter price of KES120 (US\$1.20). Approximately $98 \%$ of those who sought services from the private commercial sector were willing to pay KES150 (US\$1.50) as a starter price.

Furthermore, it is interesting to note that with price increases, although there is an expected decline in the proportion willing to pay the new price, there is also a clear pattern. At a $20 \%$ increment, respondents in the public sector are most sensitive to the price change, followed by the private nonprofit and private commercial sectors. This pattern confirms our belief that paying users of the PVR are likely to be in the private sector.

\section{WTP More for Women in Low-Resource Settings}

A significant proportion of respondents were willing to help women in low-resource settings access contraceptive services. For instance, $77 \%$ of clients (Table 11) indicated that they were willing to pay the maximum amount quoted, plus a $5 \%$ increase over the price if it can be used to fund contraceptive supply for women in low-resource settings.

TABLE 11 Respondents' WTP more to fund contraceptive supply for women in low-resource settings

\begin{tabular}{|c|c|c|c|c|c|c|c|c|}
\hline \multirow[t]{2}{*}{ Response } & \multicolumn{2}{|c|}{ Public Sector $(n=190)$} & \multicolumn{2}{|c|}{$\begin{array}{l}\text { Private Nonprofit } \\
\text { Sector }(n=9)\end{array}$} & \multicolumn{2}{|c|}{$\begin{array}{l}\text { Private Commercial } \\
\text { Sector }(n=68)\end{array}$} & \multicolumn{2}{|c|}{ Total } \\
\hline & $\mathrm{n}$ & $\%$ & $n$ & $\%$ & $\mathrm{n}$ & $\%$ & $\mathrm{n}$ & $\%$ \\
\hline Yes, willing to pay & 140 & 74 & 6 & 67 & 59 & 87 & 205 & 77 \\
\hline $\begin{array}{l}\text { No, not willing to } \\
\text { pay }\end{array}$ & 42 & 22 & 3 & 33 & 8 & 12 & 53 & 20 \\
\hline Do not know & 8 & 4 & 0 & 0 & 1 & 1 & 9 & 3 \\
\hline Total & 190 & 100 & 9 & 100 & 68 & 100 & 267 & 100 \\
\hline
\end{tabular}

\section{WTP Maximum Price for the PVR}

As shown in Table 12, 94\% of clients were willing to pay less than KES500 (US\$5) for the PVR. Of those respondents who were willing to pay less than KES500 (US\$5), 98\% sought services from the public sector and $100 \%$ from the private nonprofit sector. At least $6 \%$ of clients were willing to pay more than KES500 (US\$5) for the PVR.

TABLE 12 Respondents WTP maximum price for the PVR

\begin{tabular}{|c|c|c|c|c|c|c|c|c|}
\hline \multirow[t]{2}{*}{$\begin{array}{l}\text { Maximum } \\
\text { Price (KES) }\end{array}$} & \multicolumn{2}{|c|}{ Public Sector ( $n=191)$} & \multicolumn{2}{|c|}{$\begin{array}{l}\text { Private Nonprofit } \\
\text { Sector }(n=9)\end{array}$} & \multicolumn{2}{|c|}{$\begin{array}{l}\text { Private Commercial } \\
\text { Sector }(n=69)\end{array}$} & \multicolumn{2}{|c|}{ Total } \\
\hline & $n$ & $\%$ & $n$ & $\%$ & $n$ & $\%$ & $\mathrm{n}$ & $\%$ \\
\hline$<500$ & 188 & 98 & 9 & 100 & 57 & 83 & 254 & 94 \\
\hline $500-1,000$ & 2 & 1 & 0 & 0 & 9 & 13 & 11 & 4 \\
\hline $1,000-1,500$ & 0 & 0 & 0 & 0 & 3 & 4 & 3 & 1 \\
\hline$>1,500$ & 1 & 1 & 0 & 0 & 0 & 0 & 1 & 1 \\
\hline Total & 191 & 100 & 9 & 100 & 69 & 100 & 269 & 100 \\
\hline
\end{tabular}




\section{Reasons for Agreeing to Pay}

Those respondents who agreed to pay more, including a 5\% increase, cited a number of reasons for doing so. Some said that the price was affordable and desired an FP method for use during the postpartum period. Others reported that an unintended pregnancy could lead to medical complications and higher expenses in the management of such complications. Hence paying for an FP method instead of anticipating complications related to pregnancy was the rationale. The respondents who were not willing to pay more, including a $5 \%$ increase over the price, believed that the price was too high and noted the fact that there were less expensive alternatives on the market.

\section{Suppose the Selling Price of the PVR Is Too High?}

A majority of the respondents said that they would look for affordable alternatives (52\%) and go to places where the PVR is given free of charge (27\%) if the selling price of the PVR turns out to be too high for them. Most of the respondents who cited affordability issues sought services from the private nonprofit sector followed by those who sought services from the public sector.

\section{Consumer Demand Curve for PVR by Sector}

In this section, two sets of consumer demand curves for the PVR are shown, namely the public and private commercial sectors. The demand curve for the private sector combines the clients who were seen in the private nonprofit and private commercial sectors. Combining views of clients from the private commercial sector and those of clients who were seen at the private nonprofit facilities was done due to the small sample size for the latter group.

\section{Public Sector Consumer Demand Curve}

As shown in Figure 2, a majority of respondents in the public sector were willing to pay up to KES500 (US\$5) for the PVR. The proportion of respondents who were willing to pay between KES500 (US\$5) and KES2,100 (US\$21) for the PVR drops dramatically at prices over KES500 and is almost negligible among public sector clients.

FIGURE 2 CONSUMER DEMAND CURVE FOR THE PVR-PUBLIC SECTOR

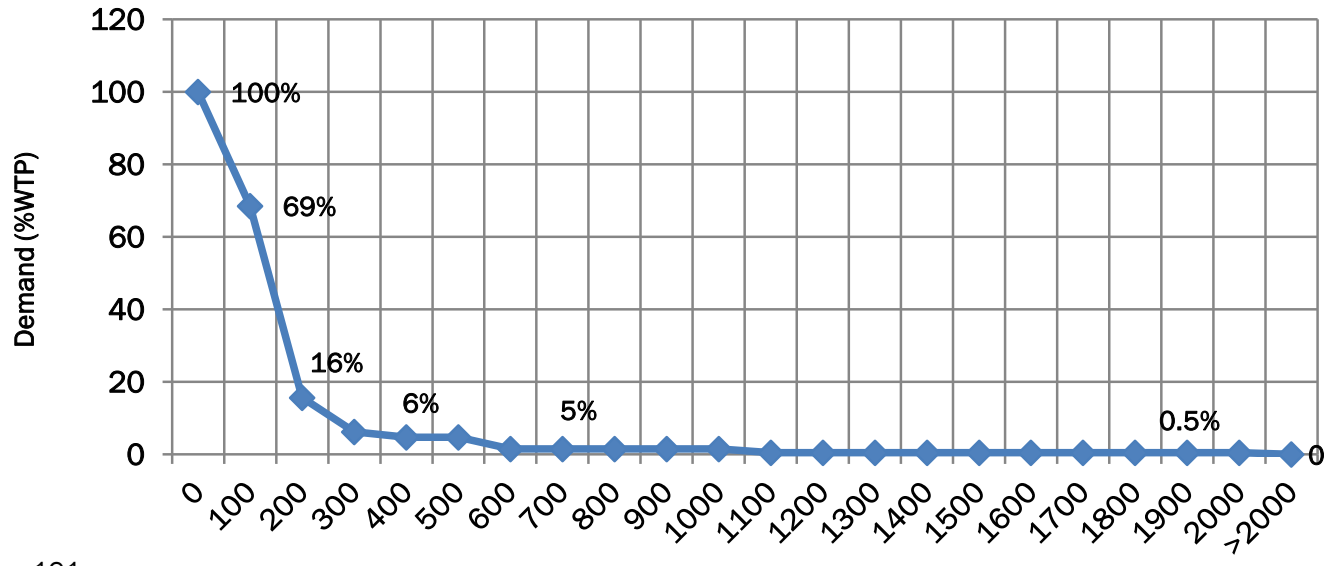

$n=191$

Maximum Price (KES) 
The steep drop in the demand for the PVR if the price exceeds KES500 (US\$5) could be attributed to low income levels in the target community or among potential users. For instance, when public sector respondents were asked what form of transportation they used to travel to work, school or market, roughly $50 \%$ reported using public transportation, $41 \%$ said they walked, and $1 \%$ reported owning a vehicle. As noted earlier, the mean hair salon expense per visit for public sector respondents was KES660 (US\$6.60). These respondents also made less visits to the salon compared to clients who sought FP services in the private sector.

\section{Private Sector Consumer Demand Curve}

As seen in Figure 3, the consumer demand curve for private sector respondents was less steep. For instance, a significant proportion of the clients were willing to pay for the PVR even if the price exceeded KES500 (US\$5).

\section{FIGURE 3 CONSUMER DEMAND CURVE FOR THE PVR-PRIVATE NONPROFIT AND COMMERCIAL SECTORS}

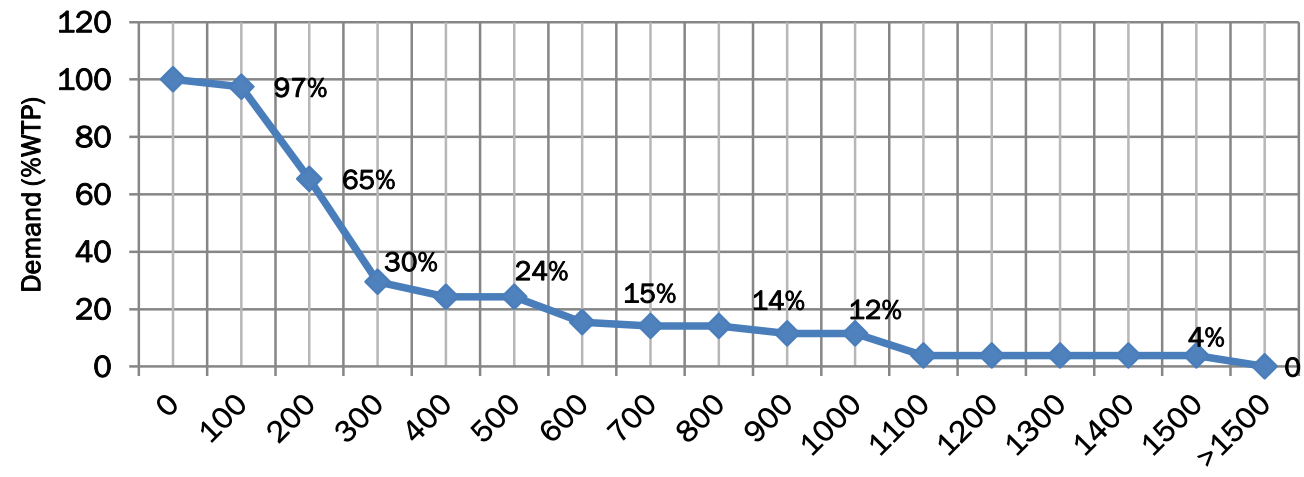

Maximum Price (KES)

$\mathrm{n}=78$

The shape of the consumer demand curve for the private sector is consistent with the observation made earlier (see Table $7 b$ ) regarding visits to hair salons. The mean salon expense per visit for private sector respondent was KES1,160 (US \$11.6) and private sector respondents made more weekly visits to salons compared to public sector respondents.

In addition, about $70 \%$ of private sector clients were willing to pay for contraceptives, compared to only $30 \%$ of the clients who sought services from the public sector health facilities.

\section{Reasons for WTP for the PVR}

Respondents cited many reasons for their willingness to pay for the PVR (Figure 4). For instance, 45\% of the private sector respondents and $35 \%$ of the public sector respondents mentioned an "affordable price." Other responses included:

- Provider recommendation (public sector $11 \%$, private sector $9 \%$ );

- Wanting or liking the method (public sector $19 \%$, private sector $18 \%$ );

- Do not want unintended pregnancy (public sector $16 \%$, private sector $23 \%$ ); and

- I want to help women get access to this FP method (public sector 51\%, private sector $46 \%$ ). 
It is worth pointing out that except for in the case of affordability, where the proportion of respondents in the private sector was clearly greater than that in the public sector, the rest of the responses were more or less similar across sectors. The least cited reason for respondents' willingness to pay for the PVR was a "provider recommendation," which was only cited by $11 \%$ in the public sector and $9 \%$ in the private sector.

FIGURE 4 REASONS FOR WTP FOR THE PVR BY SECTOR

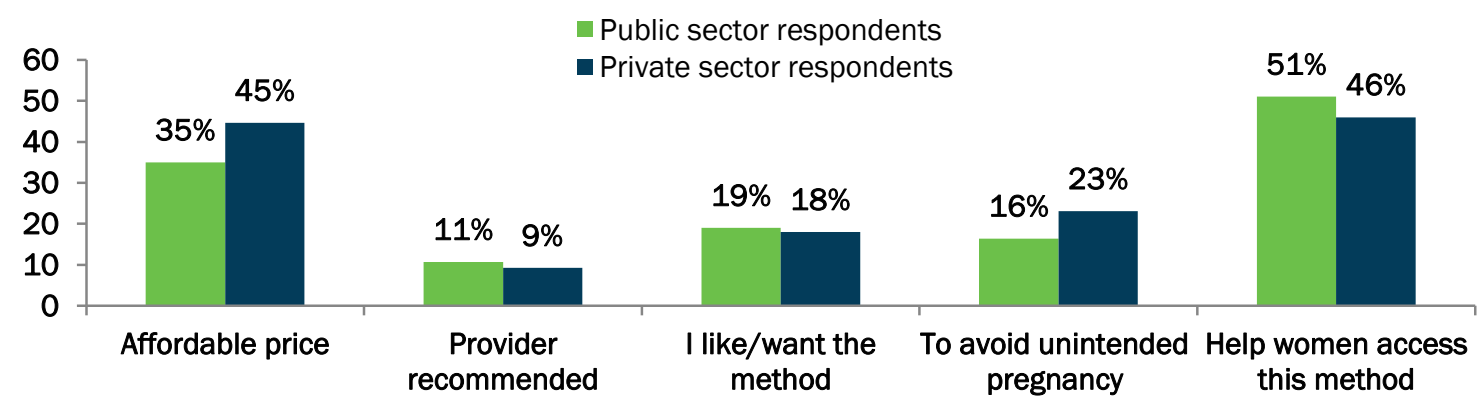

\section{WTP for a One-Year Contraceptive Vaginal Ring (CVR) for Nonbreastfeeding Women}

Respondents who participated in the WTP for the PVR were also asked if they would be interested in using a new type of method with different features, namely a long-acting reversible contraceptive vaginal ring (CVR) for nonbreastfeeding women. Since the nonbreastfeeding ring is a new product, respondents were provided with a full product description including its use and benefits, and the fact that it can be used for up to one year and is meant for nonbreastfeeding women. Examples were given to draw connections with comparable products such as implants.

To reduce bias, user interest was ascertained by providing an option to rate interest in the one-year CVR before proceeding with the interview. Thus, we specifically asked if they would be interested in using a new type of contraceptive method that is long-acting and reversible for nonbreastfeeding women. Uninterested respondents were not interviewed.

Different WTP price references for the long-acting ring for nonbreastfeeding women were used depending on the type of sector where clients who were interviewed had gone to seek services. The current price of providing long-acting and reversible FP methods such as implants in the public, private nonprofit, and private commercial sectors was used in estimating the potential market price for the long-acting ring for nonbreastfeeding women. We ended the interview by asking the maximum price that the participant was willing to pay for the one-year CVR independent of the previously mentioned prices. 
The responses from clients with regard to their interest in using the one-year CVR are outlined in Table 13.

TABLE 13 Respondents' interest in the one-year CVR

\begin{tabular}{lcccccccc}
\hline Response & $\begin{array}{c}\text { Public Sector } \\
(n=268)\end{array}$ & \multicolumn{2}{c}{$\begin{array}{c}\text { Private Nonprofit } \\
\text { Sector }(n=13)\end{array}$} & $\begin{array}{c}\text { Private Commercial } \\
\text { Sector }(n=98)\end{array}$ & \multicolumn{2}{c}{ Total } \\
\hline Yes, interested & $n$ & $\%$ & $n$ & $\%$ & $n$ & $\%$ & $n$ & $\%$ \\
No, not interested & 177 & 66 & 11 & 85 & 61 & 62 & 249 & 66 \\
Total & 91 & 34 & 2 & 15 & 37 & 38 & 130 & 34 \\
\hline
\end{tabular}

Most of the respondents (66\%) in the public sector reported being interested in the one-year CVR. Respondents who sought services in the private nonprofit sector (85\%) were most likely to agree to use the one-year CVR compared to $66 \%$ in the public sector and $62 \%$ in the private commercial sector.

\section{Reference Prices for WTP for the One-Year CVR}

The reference WTP prices for the one-year CVR are shown in Table 14.

TABLE 14 Reference WTP Prices for the One-Year CVR

\begin{tabular}{l|c|c|c}
\hline & Public Sector (KES) & $\begin{array}{c}\text { Private Nonprofit } \\
\text { Sector (KES) }\end{array}$ & $\begin{array}{c}\text { Private Commercial } \\
\text { Sector (KES) }\end{array}$ \\
\hline Starter price & 640 (US $\$ 6.40)$ & $730($ US $\$ 7.30)$ & $915($ US $\$ 9.15)$ \\
Price after 10\% increase & $705($ US $\$ 7.05)$ & $800($ US $\$ 8.00)$ & $1,005($ US $\$ 10.05)$ \\
Price after 20\% increase & $770($ US $\$ 7.70)$ & $880($ US $\$ 8.80)$ & $1,100($ US $\$ 11.00)$ \\
Price after 5\% decrease & $610($ US $\$ 6.10)$ & $695($ US $\$ 6.95)$ & $870($ US $\$ 8.70)$ \\
\hline
\end{tabular}

\section{WTP for the One-Year CVR}

Respondents who had expressed interest in the one-year CVR were asked a series of questions to gauge their interest and willingness to pay the starter price, at a $10 \%$ increment, and at a $20 \%$ increment. The responses to the respective questions are outlined in Table 15.

TABLE 15 WTP for the one-year CVR by starter price, level of increment, and sector

\begin{tabular}{|c|c|c|c|c|c|c|c|c|}
\hline & \multicolumn{2}{|c|}{$\begin{array}{l}\text { Public Sector } \\
(n=177)\end{array}$} & \multicolumn{2}{|c|}{$\begin{array}{l}\text { Private Nonprofit } \\
\text { Sector }(n=11)\end{array}$} & \multicolumn{2}{|c|}{$\begin{array}{l}\text { Private Commercial } \\
\text { Sector }(n=61)\end{array}$} & \multicolumn{2}{|c|}{ Total } \\
\hline & $n$ & $\%$ & $n$ & $\%$ & $n$ & $\%$ & $\mathrm{n}$ & $\%$ \\
\hline $\begin{array}{l}\text { Respondents interested } \\
\text { in the one-year CVR }\end{array}$ & 177 & 66 & 11 & 85 & 61 & 62 & 249 & 66 \\
\hline Starter price & 89 & 50 & 7 & 64 & 43 & 71 & 139 & 56 \\
\hline $10 \%$ increment & 56 & 63 & 3 & 43 & 33 & 75 & 92 & 66 \\
\hline $20 \%$ increment & 42 & 75 & 3 & 100 & 30 & 91 & 75 & 82 \\
\hline
\end{tabular}


A significant proportion of respondents were willing to pay for the one-year CVR even at higher prices. A majority of clients interviewed in the private commercial sector were willing to pay for the one-year CVR compared with those interviewed in the public and private nonprofit sectors. Public (50\%), private nonprofit (64\%), and private commercial sectors (71\%) expressed their willingness to pay for the one-year CVR at the starter price.

\section{WTP Maximum Price for the One-Year CVR}

The responses on the maximum amount of money respondents would be willing to pay for the one-year CVR are shown in Table 16.

TABLE 16 Respondents WTP maximum price for one-year CVR

\begin{tabular}{|c|c|c|c|c|c|c|c|c|}
\hline \multirow[t]{2}{*}{ Max Price (KES) } & \multicolumn{2}{|c|}{ Public Sector $(n=175)$} & \multicolumn{2}{|c|}{$\begin{array}{l}\text { Private Nonprofit } \\
\text { Sector }(n=11)\end{array}$} & \multicolumn{2}{|c|}{$\begin{array}{l}\text { Private Commercial } \\
\text { Sector }(n=60)\end{array}$} & \multicolumn{2}{|c|}{ Total } \\
\hline & $n$ & $\%$ & $n$ & $\%$ & $n$ & $\%$ & $n$ & $\%$ \\
\hline$<500$ & 97 & 55 & 6 & 55 & 15 & 25 & 118 & 48 \\
\hline $500-1,000$ & 74 & 42 & 4 & 36 & 18 & 13 & 96 & 39 \\
\hline $1,000-1,500$ & 1 & 1 & 1 & 9 & 11 & 18 & 13 & 5 \\
\hline$>1,500$ & 3 & 2 & 0 & 0 & 16 & 27 & 19 & 8 \\
\hline Total & 175 & 100 & 11 & 100 & 60 & 100 & 246 & 100 \\
\hline
\end{tabular}

About half (48\%) of the respondents were willing to pay less than KES500 (US\$5). The clients interviewed in public sector were the majority in this category (55\%), compared to private commercial respondents where $25 \%$ agreed to pay less than KES500 (US \$5).

\section{WTP Maximum Price Plus a 5\% Increase}

A significant proportion of respondents were willing to help women in low-resource settings access the one-year CVR. For instance, $66 \%$ of women were willing to pay the maximum price plus a $5 \%$ increase over the maximum price if it can help widen FP access to women in low-resource settings (Table 17). About $77 \%$ of the respondents who were willing to pay the maximum price plus a $5 \%$ increment were in the private commercial sector.

TABLE 17 Respondents WTP maximum price plus a 5\% increase

\begin{tabular}{lcccccccc}
\hline \multicolumn{1}{c}{ Response } & \multicolumn{2}{c}{$\begin{array}{c}\text { Public Sector } \\
(\mathrm{n}=190)\end{array}$} & \multicolumn{2}{c}{$\begin{array}{c}\text { Private Nonprofit } \\
\text { Sector }(\mathrm{n}=9)\end{array}$} & $\begin{array}{c}\text { Private Commercial } \\
\text { Sector }(\mathrm{n}=68)\end{array}$ & \multicolumn{2}{c}{ Total } \\
\hline & $\mathrm{n}$ & $\%$ & $\mathrm{n}$ & $\%$ & $\mathrm{n}$ & $\%$ & $\mathrm{n}$ & $\%$ \\
\hline Yes, willing to pay & 106 & 63 & 6 & 55 & 44 & 77 & 156 & 66 \\
No, not willing to pay & 55 & 33 & 5 & 45 & 11 & 19 & 71 & 30 \\
Do not know & 7 & 4 & 0 & 0 & 2 & 4 & 9 & 4 \\
Total & 168 & 100 & 11 & 100 & 57 & 100 & 236 & 100 \\
\hline
\end{tabular}




\section{Consumer Demand Curve for One-Year CVR}

In this section, two sets of consumer demand curves for the one-year CVR are shown, namely the public and private commercial sectors. The demand curve for the private sector combines the clients who were seen at the private nonprofit and private commercial facilities due to the small sample size for the latter group.

\section{Public Sector Consumer Demand Curve}

As shown in Figure 5, approximately $50 \%$ of the respondents in the public sector were willing to pay KES700 (US\$7) for the one-year CVR. The WTP drops off substantially and tapers to less than $10 \%$ at prices over KES1,200, although there were a few potential clients who were willing to pay up to KES3,000 (US\$30).

FIGURE 5 CONSUMER DEMAND FOR ONE-YEAR CVR-PUBLIC SECTOR

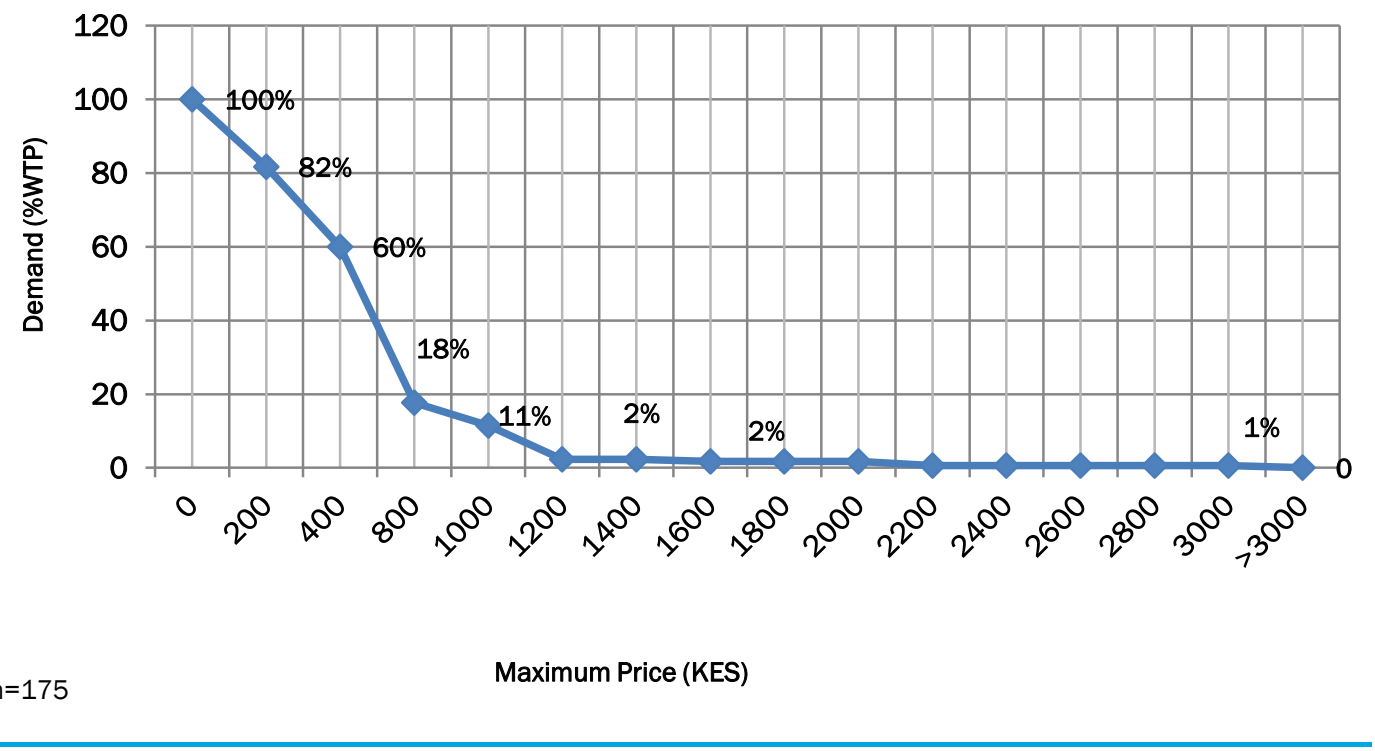

\section{Private Sector Consumer Demand Curve}

Compared to the demand curve in the public sector, the slope of the private sector demand curve is more gradual. As shown in Figure 6, approximately $50 \%$ of the respondents in the private sector were willing to pay KES1,250 (US\$12.5) for the one-year ring, with a significant proportion (23\%) willing to pay KES2,000. A few of the potential clients suggested they would pay up to KES4,000 (US\$40).

As seen in Figures 5 and 6, private sector clients were willing to pay a higher price for the one-year ring compared to public sector clients. 
FIGURE 6 CONSUMER DEMAND FOR ONE-YEAR CVR-PRIVATE NONPROFIT AND COMMERCIAL SECTORS

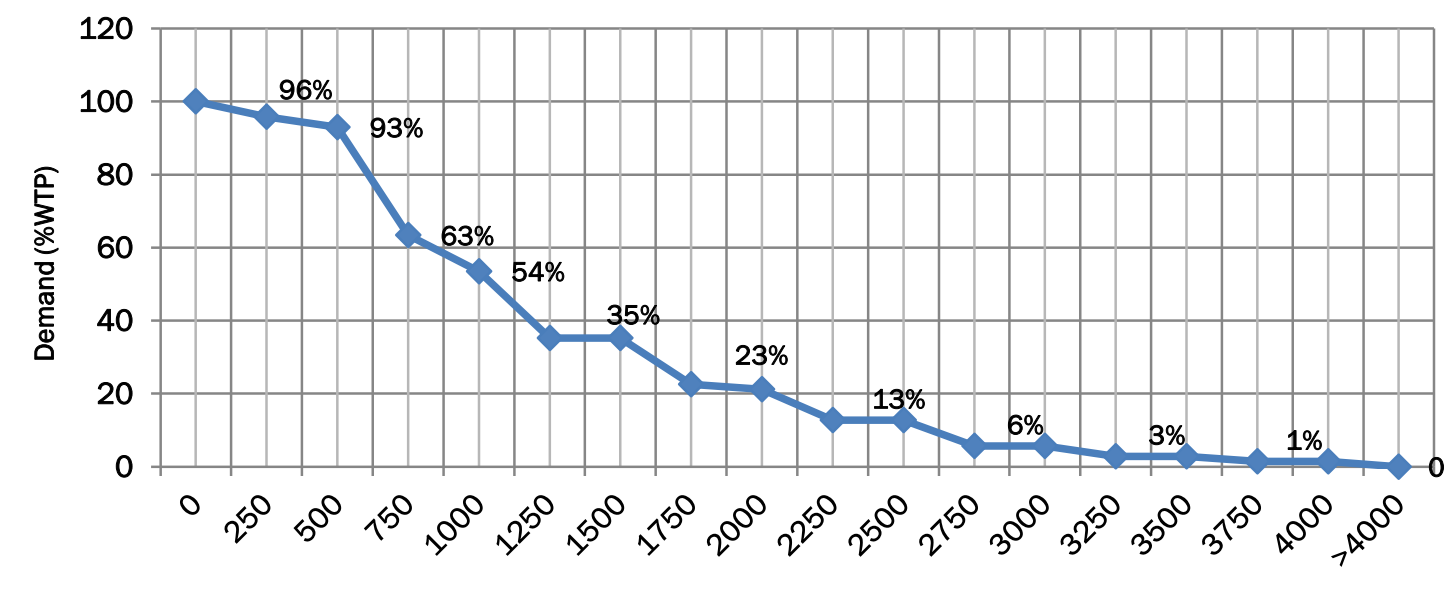

$\mathrm{n}=71$

Maximum Price (KES)

\section{PROVIDER SURVEY}

Sixty-four (64) providers were interviewed (17 from the public sector, 6 from the nonprofit private sector, and 41 from the private commercial sector). Sixty-two (62) of the providers had a college/university level of education, while two (2) had a secondary level of education. It should also be noted that the most popular methods on the market among clients are injectables, implants, and pills.

\section{Inclusion of the PVR into Available Contraception Options}

Research assistants were required to show a sample of the PVR to respondents as well as give them a brief description of the product including what it is and how it works. After providing a description of the product, respondents were then asked if they would support the inclusion of the PVR in the available FP options. Out of the 64 providers, nearly all of them (98\%) said they would support the inclusion of the PVR. Only one respondent (2\%) answered otherwise.

In a related question, providers were requested to mention the most important reason for liking the PVR. Most of them cited "easy to use" (60\%).

\section{Willingness to Provide the PVR to Clients If It Becomes Available}

Providers were asked whether they would be willing to provide the product to their clients if it becomes available. In response to this question, all 64 providers (100\%) answered in the affirmative. Providers also gave an opinion on whether their clients would like the PVR. About $75 \%$ of providers suggested that their clients would like the product. Close to $10 \%$ indicated that their clients would not like the product, and the remaining $15 \%$ indicated that they did not know. 


\section{Providers' Opinion Regarding Price for the PVR}

Providers were asked to give an opinion on what they thought was an appropriate price for the PVR. Table 18 shows the smallest and the highest amount of money suggested by providers in each sector with the corresponding interquartile range, mean, and median amount.

TABLE 18 Providers' opinion on appropriate price for the PVR by sector

\begin{tabular}{l|c|c|c|c|c|c}
\hline Sector & $\mathrm{n}$ & $\begin{array}{c}\text { Smallest Amount } \\
(\mathrm{KES})\end{array}$ & $\begin{array}{c}\text { Highest Amount } \\
(\mathrm{KES})\end{array}$ & $\begin{array}{c}\text { Interquartile Range } \\
(\mathrm{KES})\end{array}$ & Mean (KES) & Median (KES) \\
\hline Public & 16 & $50(\mathrm{US} \$ 0.5)$ & $100(\mathrm{US} \$ 1)$ & $50(\mathrm{US} \$ 0.5)$ & $78(\mathrm{US} \$ 0.78)$ & $100(\mathrm{US} \$ 1)$ \\
Donors & 6 & $50(\mathrm{US} \$ 0.5)$ & $3,000(\mathrm{US} \$ 30)$ & $150(\mathrm{US} \$ 1.5)$ & $583(\mathrm{US} \$ 5.83)$ & $100(\mathrm{US} \$ 1)$ \\
Private nonprofit & 38 & $0(\mathrm{US} \$ 0)$ & $8,000(\mathrm{US} \$ 80)$ & $400(\mathrm{US} \$ 4)$ & $697(\mathrm{US} \$ 6.97)$ & $200(\mathrm{US} \$ 2)$ \\
Private commercial & 60 & $0(\mathrm{US} \$ 0)$ & $8,000(\mathrm{US} \$ 80)$ & $200(\mathrm{US} \$ 2)$ & $521(\mathrm{US} \$ 5.21)$ & $100(\mathrm{US} \$ 1)$ \\
\hline
\end{tabular}

The median price suggested for the PVR was KES100 (US\$1) in both the public and private nonprofit sectors. Compared to the public sector, mean and interquartile range was much higher in the private nonprofit sector. The median price for the PVR in the private commercial sector was KES200 (US\$2) with a much larger interquartile range and mean compared to the public and private nonprofit sectors. Some of the providers suggested that an appropriate price for the PVR would be KES8,000 (US $\$ 80$ ).

\section{Assessing Health Providers' Interest in the One-Year CVR}

Providers were asked whether they would be interested in the one-year CVR. Out of the 64 providers interviewed, 59 of them (93\%) responded in the affirmative. Only four (6\%) were not interested. In a related question, providers were requested to mention the most important reason for liking the one-year CVR. Most of them cited the following reasons: long-acting (73\%), used for nonbreastfeeding women (2\%), and other (25\%). (Data not shown.)

\section{Willingness to Provide the One-Year CVR If It Becomes Available}

All 59 providers (100\%) said that they were willing to provide the one-year CVR to their clients if it becomes available. Out of the 59 providers, $86 \%$ said that their clients would like the one-year CVR, $2 \%$ said that their clients would not like it, and $12 \%$ said that they did not know. (Data not shown.)

\section{Providers' Opinion Regarding Price for the One-Year CVR}

Providers were asked to give an opinion on what they thought was an appropriate price for the long-acting ring for nonbreastfeeding women. Table 19 shows the smallest and the highest amount of money suggested by providers in each sector with the corresponding interquartile range, mean, and median amount.

TABLE 19 Providers' opinion on appropriate price for the one-year CVR by sector

\begin{tabular}{|c|c|c|c|c|c|c|}
\hline Sector & $n$ & $\begin{array}{c}\text { Smallest Amount } \\
\text { (KES) }\end{array}$ & $\begin{array}{l}\text { Highest Amount } \\
\text { (KES) }\end{array}$ & $\begin{array}{l}\text { Interquartile range } \\
\text { (KES) }\end{array}$ & Mean (KES) & $\begin{array}{l}\text { Median } \\
\text { (KES) }\end{array}$ \\
\hline Public & 16 & 20 (US\$0.2) & 500 (US\$5) & 150 (US\$1.50) & 176 (US\$1.76) & 100 (US\$1) \\
\hline Donors & 5 & 30 (US\$0.3) & 8500 (US\$85) & 1050 (US\$10.50) & 2076 (US\$20.76) & 400 (US\$4) \\
\hline Private nonprofit & 36 & 100 (US\$1) & 10,000 (US\$100) & 750 (US\$7.5) & 1,088 (US\$10.88) & 500 (US\$5) \\
\hline Private commercial & 57 & 20 (US\$0.2) & 10,000 (US\$100) & 300 (US\$3) & 918 (US\$9.18) & 300 (US\$3) \\
\hline
\end{tabular}


The median price for the one-year CVR was KES100 (US\$1) in the public sector. The median price in the private nonprofit sector was KES500 (US\$5) with a much larger interquartile range of KES750 (US\$7.5) and mean of KES1,088 (US\$10.88) compared to the public sector. The median price for the one-year CVR in the private commercial sector was KES300 (US\$3) with an interquartile range of KES300 (US\$3) and mean of KES918 (US\$9.18). Some of the providers in the private commercial sector suggested that an appropriate price for the one-year CVR would be KES10,000 (US \$100).

A comparison of the lowest and highest prices that providers were willing to pay for the PVR and one-year CVR is made in Figure 7.

\section{FIGURE 7 WTP (AS QUOTED BY PROVIDERS) FOR THE PVR AND ONE-YEAR CVR}

Smallest Price (KES) PVR

- Smallest Price (KES) One-Year CVR

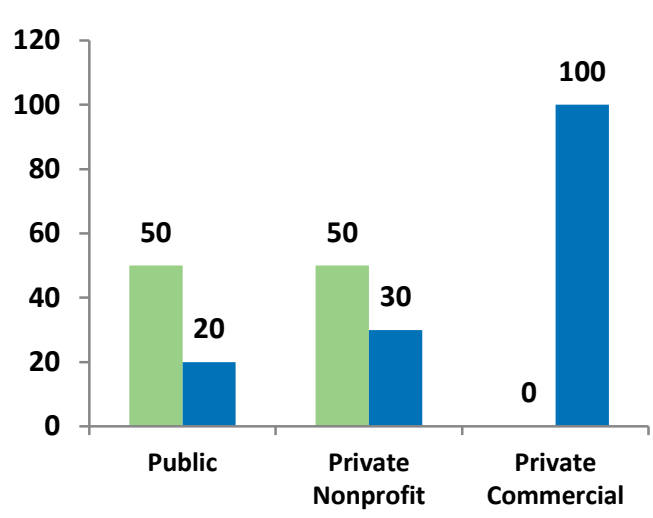

- Highest Price (KES) PVR

- Highest Price (KES) One-Year CVR

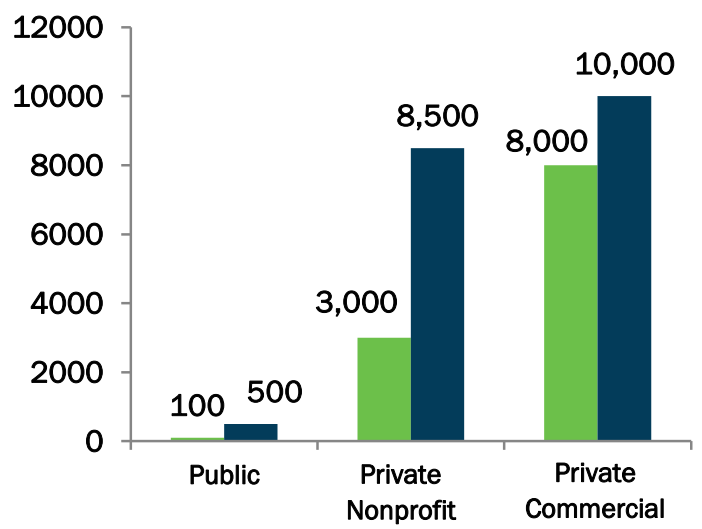

As can be seen, providers suggested much higher prices for the longer-lasting ring compared to the PVR.

\section{PROCURER SURVEY}

Twenty-three (23) procurers were interviewed-three from government, two represented donors, six from the private nonprofit sector, nine from the private commercial sector, and three others (Table 20).

The private commercial sector constituted the largest group of procurers (39\%).

TABLE 20 Procurers consulted during the PVR WTP study

\begin{tabular}{lcc}
\hline Type & Frequency $(\mathrm{n}=23)$ & Percentage \\
\hline Government & 3 & 13 \\
Donor & 2 & 9 \\
Private nonprofit & 6 & 26 \\
Private commercial & 9 & 39 \\
Other & 3 & 13 \\
Total & 23 & 100 \\
\hline
\end{tabular}




\section{Frequently Procured Contraceptive Methods}

The most frequently procured contraceptives mentioned by respondents were combined oral contraceptives (pills), injectables (DMPA), emergency contraceptive pills (Postinor-2), implants (Jadelle and Implanon), and IUDs. Other respondents said that they do obtain contraceptives from the Kenya Medical Supplies Agency (KEMSA) and then distribute or dispense to their clients.

\section{Process of Procuring Contraceptives}

Procurers were asked to describe the process of procuring contraceptives in their respective organizations. The various approaches followed in procuring contraceptives are described in Box 1.

\section{BOX 1 PROCESS OF PROCURING CONTRACEPTIVES}

- Done by national government in conjunction with KEMSA

- We usually call the suppliers and then they deliver

- We always do open tendering

- Procurement office at the head office does it for us

- We do quantification and forecasting based on consumption data

- We fill in the order form and then send it to the supplier

- We procure from importers

- We approach manufacturers directly

- We work closely with UNFPA, USAID, and the government to arrange for procurement

- Tenders are issued out, then whoever wins the tender supplies the contraceptives

- Once our products are out of stock, we call the supplier and make the order

- Most of our procuring process takes place through global partnerships

\section{Setting of Procurement Prices for Contraceptives}

Procurers were given an opportunity to describe how procurement prices for contraceptives are set in their respective organizations. The process or procedures followed in setting procurement prices for contraceptives are outlined in Box 2.

\section{BOX 2 PROCESS OF SETTING PROCUREMENT PRICES FOR CONTRACEPTIVES}

- $\quad$ The government usually initiates the process of setting procurement prices

- $\quad$ The source or type of distributor determines the price of the drugs/FP at the pharmacy

- $\quad$ Procurement prices vary a lot and are set by the supplier or importer

- Determining the price is done centrally using international mechanisms within the company, which sets the best access price

- We negotiate for the cheapest prices directly from the manufacturers

- $\quad$ Most of the time contraceptives are procured from outside Kenya and so procurement prices are set internationally depending on the strength of the dollar or some other currency

- We usually go for competitive prices. For example, the price of implants has come down because of the global commitment to get more women access to effective FP methods.

- $\quad$ Our company has already prescribed fixed prices for us. They recommend the prices we give.

- $\quad$ There are different prices for suppliers and retailers. Supplier prices are done at the national level.

- $\quad$ Other organizations negotiate with manufacturers so that the contraceptives can be purchased at the lowest possible price depending on the strength of the dollar and yen. 


\section{Frequency of Changes in Procurement Costs}

Procurers were asked to describe the frequency of changes in procurement costs for contraceptives. Different groups of procurers made the statements outlined in Box 3.

\section{BOX 3 FREQUENCY OF CHANGES IN PROCUREMENT COSTS}

- $\quad$ Procurement costs vary monthly and depend on agents, distributors, or suppliers. When the supplier increases the price, the chemists also increase the retail price. If they drop the price, the retail price also drops.

- $\quad$ Depends on demand. Sometimes the prices change twice a year.

- Procurement costs rarely change. Sometimes they change annually. Prices could either increase or decrease depending on demand and supply forces.

- Usually increase due to additional annual taxation

- We get most of the FP supplies from the Ministry of Health so we do not experience price changes

- Changes in procurement costs depend on the raw materials, the cost to the government, and market prices

- $\quad$ Price changes are dependent on what the manufacturer gives distributors or procurers

- $\quad$ Price changes are not very common since we buy directly from a company (we try to keep it fixed)

- $\quad$ Procurement costs hardly change. Maybe after every 5 years.

- $\quad$ Procurement costs depend on the strength of the dollar and yen because most of the FP products are manufactured overseas and so it would be difficult to answer this question directly

\section{Family Planning Commodity Prices, Taxation, and Markup}

Procurers were asked to confirm or acknowledge if pricing included taxes and markups. Their responses are outlined in Table 21. About half of the respondents did not know whether the price charged included a markup. A much bigger proportion (61\%) of respondents said that the commodity prices did not include taxes.

TABLE 21 Procurers' views on commodity pricing, taxes, markup, and levels involved

\begin{tabular}{lccl}
\hline \multicolumn{1}{c}{ Type } & $n$ & Percentage & Estimated Proportion of Taxation (for Yes Response) \\
\hline $\begin{array}{l}\text { Response (Taxation) } \\
\begin{array}{l}\text { Yes (pricing including } \\
\text { taxation) }\end{array}\end{array}$ & 9 & 39 & $\begin{array}{l}\text { 16\% (Value Added Tax); others said that taxes are included } \\
\text { in the pricing but did not know the rate or percentage. } \\
\text { No }\end{array}$ \\
$\begin{array}{l}\text { Response (Markup) } \\
\begin{array}{l}\text { Yes (pricing including } \\
\text { markup) }\end{array}\end{array}$ & 14 & 61 & N/A \\
No & 12 & 52 & Ranges from 1.33\% to 30\% \\
\hline
\end{tabular}

\section{Quality Control Process for Procurement of New Contraceptives}

Procurers were asked to describe the quality-control process that their respective organizations must follow when procuring new contraceptives. Some of the examples that were offered by data collectors (during the discussion) to clarify the question included WHO PQ, EML, and SRA. The responses to this question are outlined in Table 22. 
TABLE 22 Quality-control process followed to procure new contraceptives

\begin{tabular}{lcc}
\hline Type & $\mathrm{n}$ & Percentage \\
\hline Follow quality-control standards of WHO/MOH/KEMSA & 11 & 48 \\
Organization has an internal quality-control department that assesses quality issues & 3 & 13 \\
Purchase only products that are already registered in Kenya & 5 & 22 \\
Organization manufactures commodities and has an internal mechanism for quality & 3 & 13 \\
assurance and appropriate infrastructure to maintain recommended conditions. & 1 \\
Buy commodities only from reliable sources & 23 \\
Total & 4 \\
\hline
\end{tabular}

The majority of respondents cited the quality-control process mandated by WHO and KEMSA as being the reference point to be followed in procuring new contraceptives.

\section{Assessing Procurers' Interest in Purchasing the PVR}

Procurers were asked whether they would be willing to purchase the PVR if it becomes available. In response to this question, 19 out of the 23 procurers (83\%) answered in the affirmative (Table 23). The four procurers who showed no interest in purchasing the PVR are not involved in FP commodities. The four procurers were all from the private commercial sector.

TABLE 23 Assessing procurers' interest in purchasing the PVR

\begin{tabular}{lccc}
\hline Type & \multicolumn{2}{c}{ Response } & Total \\
\hline & Interested & Not Interested & \\
\hline Government & 3 & 0 & 3 \\
Donor & 2 & 0 & 2 \\
Private nonprofit & 6 & 0 & 6 \\
Private commercial & 5 & 4 & 9 \\
Others & 3 & 0 & 3 \\
Total & 19 & 4 & 23 \\
\hline
\end{tabular}

\section{Procurers' WTP Maximum Price for the PVR}

The responses on the maximum amount of money procurers would be willing to pay for the PVR are shown in Table 24.

TABLE 24 Procurers' opinion on appropriate price for PVR by sector

\begin{tabular}{|c|c|c|c|c|c|c|}
\hline Sector & $\mathrm{n}$ & $\begin{array}{c}\text { Smallest Amount } \\
\text { (KES) }\end{array}$ & $\begin{array}{c}\text { Highest Amount } \\
\text { (KES) }\end{array}$ & $\begin{array}{l}\text { Interquartile range } \\
\text { (KES) }\end{array}$ & Mean (KES) & Median (KES) \\
\hline Public & 2 & 200 (US\$2) & 255 (US\$2.55) & 55 (US\$0.55) & 227 (US\$2.27) & 227 (US\$2.27) \\
\hline Donors & 2 & 100 (US\$1) & 500 (US\$5) & 400 (US\$4) & 868 (US\$8.68) & 300 (US\$3) \\
\hline Private nonprofit & 5 & 0 (US\$O) & 850 (US\$8.50) & 100 (US\$1) & 270 (US\$2.70) & 200 (US\$2) \\
\hline Private commercial & 5 & 90 (US\$0.9) & 3,000 (US\$30) & 950 (US\$4) & 697 (US\$6.97) & 200 (US\$2) \\
\hline $\begin{array}{l}\text { All providers } \\
\text { (combined) }\end{array}$ & 16 & 0 (US\$0) & 3,000 (US\$30) & 400 (US\$4) & 465 (US\$4.65) & 200 (US\$2) \\
\hline
\end{tabular}


The mean price for the PVR ranged from KES227 (US\$2.27) in the public sector to KES697 (US\$6.97) in the private commercial sector. A comparison of the lowest and highest prices that procurers were willing to pay for the PVR by sector is made in Figure 8.

Procurers in the private commercial sector were willing to pay the highest maximum price for the PVR.

FIGURE 8 PROCURERS' WTP MAXIMUM PRICE BY SECTOR

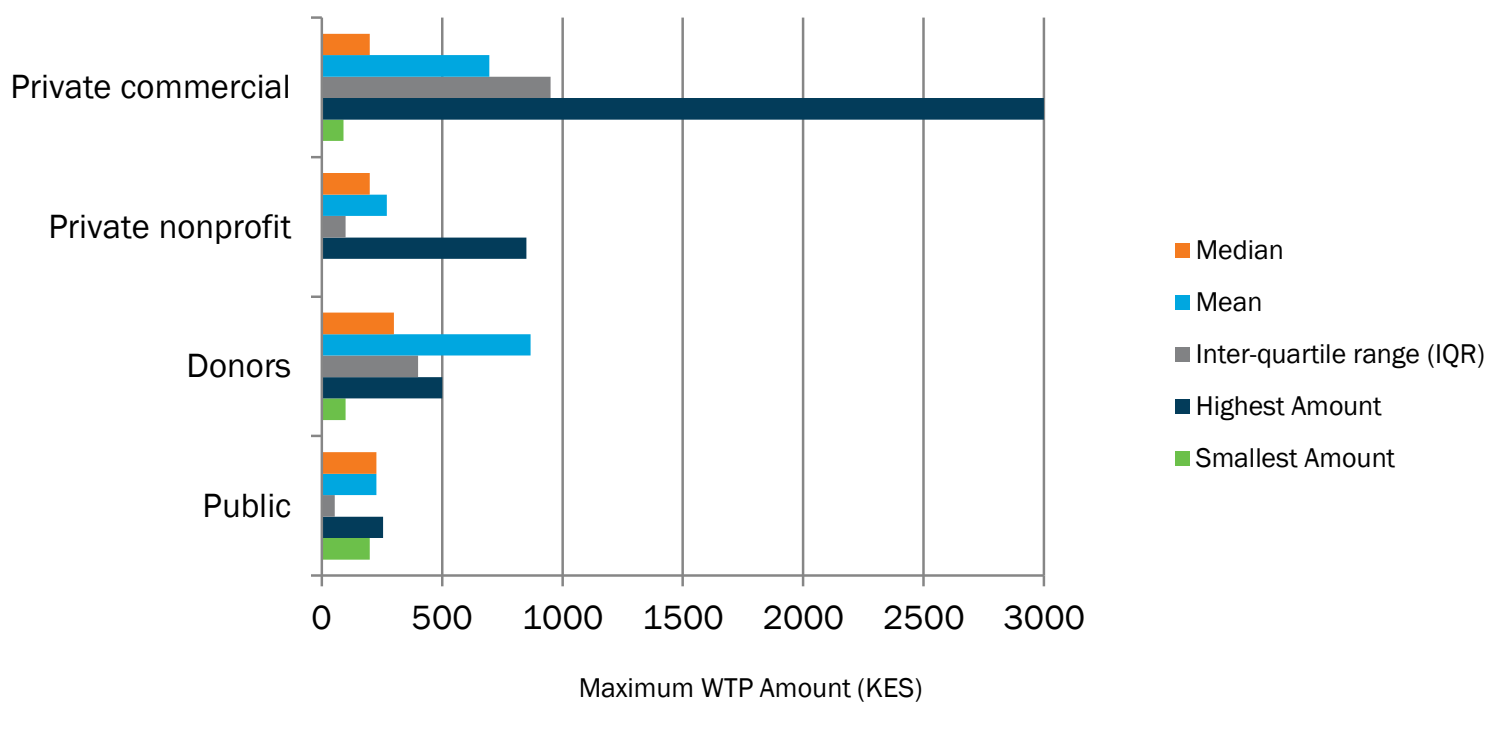

\section{Assessing Procurers' Interest in the One-Year CVR}

Procurers were asked whether they would be interested in the one-year CVR. Nearly all the procurers (95\%) responded in the affirmative, and cited many reasons why they would be interested in the one-year CVR (Table 25).

TABLE 25 Procurers' interest in the one-year CVR

\begin{tabular}{lc}
\hline \multicolumn{1}{c}{ Reason } & Frequency \\
\hline The method will provide an alternative to mothers (and address the pill burden ${ }^{9}$ ) & 2 \\
If the method is in the country and it is effective, we will of course try it. & 3 \\
If women and their partners are willing to use it, then it will widen the options available & 3 \\
If there are no complications, then it is a good product & 3 \\
We are open to any FP method that comes along as long as it is effective & 4 \\
If the method has been recommended by the Pharmacy and Poisons Board we will procure it & 1 \\
Total & 2 \\
\hline
\end{tabular}

The procurers also pointed out the following issues: information on method effectiveness and side effects should be shared widely; male involvement will be critical; emphasis needs to be made that the new method will not prevent HIV; myths need to be addressed about FP methods being inserted into the vagina.

${ }^{9}$ A complex medication regimen-daily reminders, schedules, dosage; one that taxes a patient's adherence. 


\section{Conclusion}

New product introduction strategies often suffer from a lack of available market research and rely on hypothetical approaches to gauge consumer demand. The PVR, as a new product in sub-Saharan Africa, also faces such a challenge. The Kenyan family planning program is largely a public sector program. Family planning services and contraceptives are offered free of charge in public sector facilities, and the government is the major source of contraceptives across the public, private-commercial, and private nonprofit sectors.

To prepare for and facilitate the PVR's eventual introduction into Kenya, we undertook this study to assess "Willingness to Pay," "Willingness to Provide," and "Willingness to Procure." Findings generated on all three aspects are listed below.

- Women seeking family planning services at public, nonprofit, and for-profit facilities are willing to pay for the PVR if it becomes available. A significant proportion of women who visit the private commercial sector spend KES50-199 per month on FP services and products. This implies that a market currently exists for FP products through the private commercial sector channel.

- The majority of respondents were willing to pay a price equivalent to a three-month supply of POP (Microlut) as well as a $10 \%$ increment on the price, with some variation across sectors. Respondents from public sector facilities were more sensitive to marginal price increments than those who were interviewed at private sector facilities.

- Nearly universally, health care providers (based in public, nonprofit, and private commercial facilities) indicated that the PVR is an important option to include in the choice of methods, especially in light of the frequent and prolonged stock-outs of Microlut. They are willing to counsel and provide it to users. Providers in the public and nonprofit sectors suggested a median price of KES100 (US\$1), and those in the private commercial sector proposed a median price of KES200 (US\$2).

- Procurers are willing to procure the PVR and make it available through their distribution networks and outlets. They are willing to purchase the PVR at much higher costs than what consumers had proposed.

- All key stakeholders (women, providers, and procurers in public, nonprofit, and for-profit private sectors) were interested and supportive of the one-year ring. All those interviewed were willing to pay for the long-acting ring at higher costs than the PVR. The median price for the one-year ring varied across the sectors-100KES (US\$1) in the public sector, 400KES (US\$4) in the nonprofit private sector, and 500KES (US\$5) in the private commercial sector.

- There is potential for the private sector to play an active role in FP provision that can be utilized for the introduction of the PVR. This sector can serve the segment of customers that have expressed higher levels of willingness to pay for the PVR. Social marketing organizations and commercial players can ease the burden on public health expenditure while tapping into Kenya's growing economy, presenting consumers with varying levels of ability to pay for FP products and services. 
It is important to note that some of the target groups assessed, including a number of the facilities and health providers in the nonprofit private sector, had small sample sizes compared to public and for-profit private sector teams. The study highlights the ability of public sector consumers to afford FP products and the potential for serving them via private sector mechanisms.

In terms of utilization, the results generated will inform and guide next steps about product introduction. Specifically, the findings of this study will be integrated with results from a market-segmentation exercise conducted earlier to develop a pricing model for the PVR. The price will reflect not only the COGS and cost of product introduction (training, educational material, marketing and branding, demand creation) but also the benefits to the health system (e.g., limited need for infrastructure and equipment, potential for multiple service outlets and health cadres). The results will also be useful to refine PVR market segmentation and tailor specific strategies for product introduction, including innovative financing approaches. 


\section{References}

Division of Reproductive Health (DRH)/Ministry of Public Health and Sanitation (MOPHS). 2010. National Family Planning Guidelines for Service Providers. Nairobi: DRH/MOPHS.

Foreit K.G. and J.R. Foreit. 2001. "Willingness to pay surveys for setting prices for reproductive health products and services: A user's manual." Frontiers in Reproductive Health, Population Council, Policy Project, and Futures Group International.

Gebreselassie, T., S.O. Rutstein, and V. Mishra. 2008. "Contraceptive use, breastfeeding, amenorrhea and abstinence during the postpartum period: An analysis of four countries." DHS Analytical Studies 14. Calverton, MD: Macro International.

Kenya National Bureau of Statistics (KNBS). 2015. Demographic and Health Survey Key Indicators 2014.

Kenya National Bureau of Statistics (KNBS) and ICF Macro. 2010. Kenya Demographic and Health Survey 2008-09. Calverton, MD: KNBS and ICF Macro.

National Coordinating Agency for Population and Development (NCAPD) [Kenya]. 2011. Kenya Service Provision Assessment Survey 2010. Nairobi, Kenya: NCAPD, National Bureau of Statistics, and ICF Macro.

Sonalkar et al. 2013. "Programmatic aspects of postpartum family planning in developing countries: A qualitative analysis of key informant interviews in Kenya and Ethiopia." Short Report. African Journal of Reproductive Health 17(3): 54-56. 


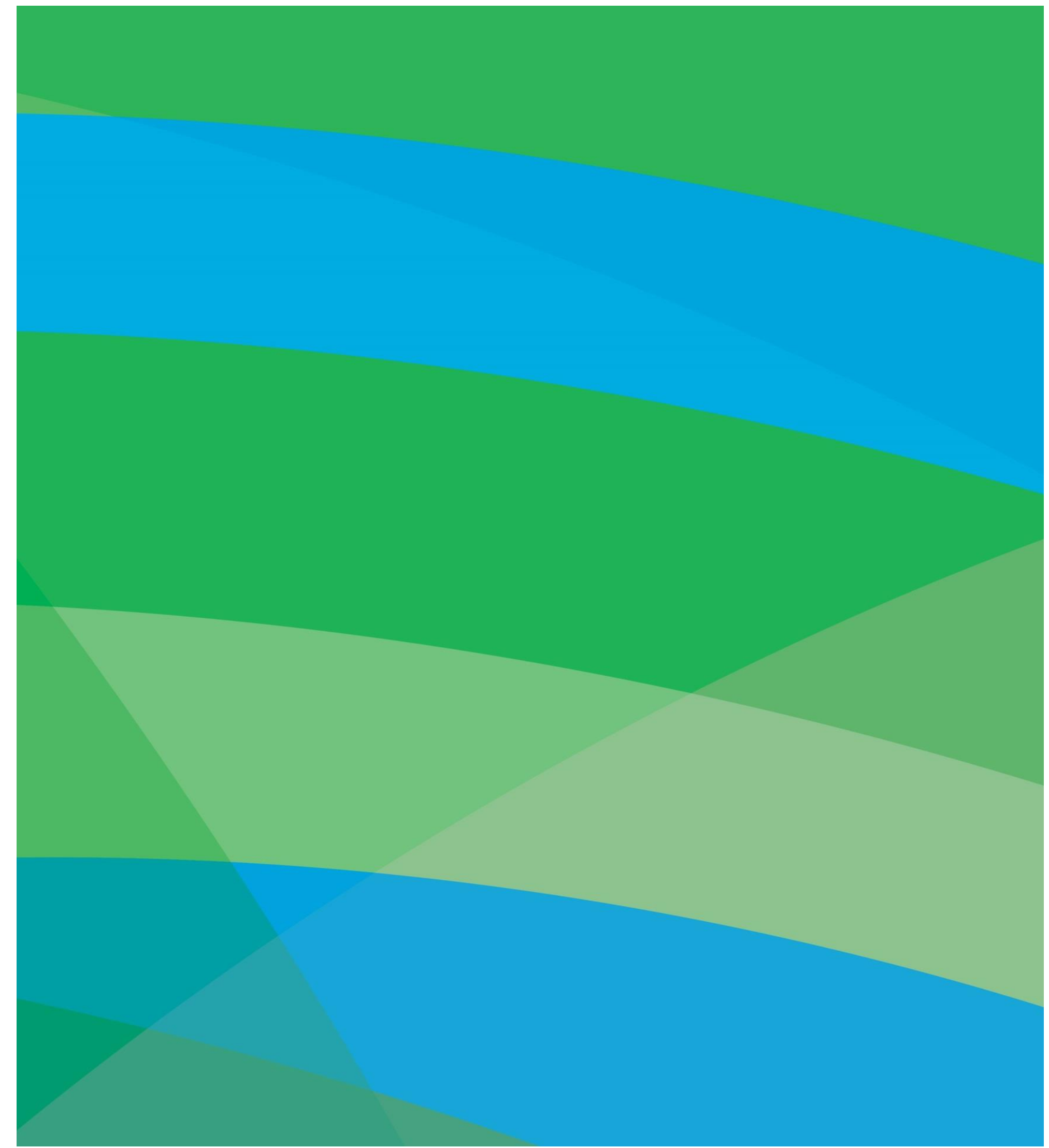

Population Council General Accident House

\section{POPULATION} COUNCIL

Ralph Bunche Road

Nairobi, Kenya

popcouncil.org 